\title{
Reactions of $\mathrm{Ru}_{3}(\mathrm{CO})_{10}(\mu-\mathrm{dppm})$ with $\mathrm{Ph}_{3} \mathrm{GeH}: \mathrm{Ge}-\mathrm{H}$ and $\mathrm{Ge}-\mathrm{C}$ bond cleavage in $\mathrm{Ph}_{3} \mathrm{GeH}$ at triruthenium clusters
}

Md. Mehedi Mahabub Khan ${ }^{a}$, Md. Mahbub Alama, Shishir Ghosha, Ahibur Rahaman $^{\mathrm{a}}$, Derek A. Tocher ${ }^{\mathrm{b}}$, Michael G. Richmond ${ }^{\mathrm{c}}$, Shariff E. Kabir ${ }^{\mathrm{a}, \mathrm{d}}$ *, Herbert W. Roesky ${ }^{\mathrm{d}} *$

a Department of Chemistry, Jahangirnagar University, Savar, Dhaka 1342, Bangladesh

${ }^{\mathrm{b}}$ Department of Chemistry, University College London, 20 Gordon Street, London WC1H $O A J, U K$

c Department of Chemistry, University of North Texas, Denton, Texas 76203, USA

${ }^{d}$ Georg-August University, Institute of Inorganic Chemistry, Tammannstr. 4, D-37077

Göttingen, Germany

*Corresponding authors.

E-mail address: skabir_ju@yahoo.com (S.E. Kabir), hroesky@gwdg.de (H.W. Roesky)

\begin{abstract}
The activation of $\mathrm{Ph}_{3} \mathrm{GeH}$ at the dppm-bridged cluster $\mathrm{Ru}_{3}(\mathrm{CO})_{10}(\mu$-dppm) [dppm = bis(diphenylphosphino)methane] has been investigated. $\mathrm{Ru}_{3}(\mathrm{CO})_{10}(\mu$-dppm) reacts with $\mathrm{Ph}_{3} \mathrm{GeH}$ at room temperature in the presence of $\mathrm{Me}_{3} \mathrm{NO}$ to give the new cluster products $\mathrm{Ru}_{3}(\mathrm{CO})_{9}\left(\mathrm{GePh}_{3}\right)(\mu-\mathrm{dppm})(\mu-\mathrm{H}) \quad$ (1) and $\quad \mathrm{Ru}_{3}(\mathrm{CO})_{8}\left(\mathrm{GePh}_{3}\right)_{2}(\mu-\mathrm{dppm})(\mu-\mathrm{H})_{2} \quad$ (2) via successive oxidation-addition of two Ge-H bonds. Refluxing $\mathbf{1}$ in THF furnishes the diruthenium complex $\mathrm{Ru}_{2}(\mathrm{CO})_{6}\left(\mu-\mathrm{GePh}_{2}\right)(\mu$-dppm) (3) as the major product (44\%), in addition to $\mathrm{Ru}_{3}(\mathrm{CO})_{7}(\mu-\mathrm{CO})\left(\mathrm{GePh}_{3}\right)\left\{\mu_{3}-\mathrm{PhPCH}_{2} \mathrm{P}(\mathrm{Ph}) \mathrm{C}_{6} \mathrm{H}_{4}\right\}(\mu-\mathrm{H})(4)$ and the known cluster $\mathrm{Ru}_{3}(\mathrm{CO})_{9}(\mu-\mathrm{H})\left(\mu_{3}-\mathrm{Ph}_{2} \mathrm{PCH}_{2} \mathrm{PPh}\right)(5)$ in 7 and $8 \%$ yields, respectively. Heating samples of cluster $\mathbf{2}$ also afforded $\mathbf{3}$ as the major product together with a small amount of $\mathrm{Ru}_{3}(\mathrm{CO})_{6}\left(\mathrm{GePh}_{3}\right)(\mu-\mathrm{OH})(\mu-\mathrm{dppm})(\mu-\mathrm{H})_{2}(6)$. DFT calculations establish the stability of the different possible isomers for clusters $\mathbf{1}, \mathbf{2}$, and $\mathbf{6}$, in addition to providing insight into the mechanism for hydride fluxionality in $\mathbf{2}$. All new compounds have been characterized by
\end{abstract}


analytical and spectroscopic methods, and the molecular structures of $\mathbf{1 ,}, \mathbf{3}$, and $\mathbf{6}$ have been established by single crystal X-ray diffraction analyses.

Keywords: Triruthenium clusters, Carbonyls, Triphenylgermanium hydride $\left(\mathrm{Ph}_{3} \mathrm{GeH}\right)$, Diphosphine, Oxidative-addition, DFT

\section{Introduction}

Both germanium [1] and tin [2,3] are employed with transition metals from Group 810 to create composite alloy systems for catalytic reforming processes. The resulting heterogeneous nanoparticle catalysts may be prepared by the deposition of a metal cluster containing a Group 14 ligand on an oxide support, yielding systems that exhibit high activity and selectivity for certain types of hydrogenation and dehydrogenation reactions [4]. We have been investigating the synthesis and structure of metal carbonyl complexes containing organogermanium and organotin ligands that can be used as precursors in the synthesis of such nanoscale catalysts during the last few years [5-8]. Ruthenium combined with the Group 14 elements, such as germanium or tin, continues to dominate the attention of different research groups with interest in catalysis [9-11]. Notwithstanding the existing literature on transition metal complexes containing Group 14 elements as ligands [12-14], well-defined examples of triruthenium clusters with an ancillary germanium ligand(s) remain scarce [1520]. The first example of a triruthenium compound containing an organogermanium moiety e.g. $\left[\left(\mathrm{Me}_{2} \mathrm{Ge}\right) \mathrm{Ru}(\mathrm{CO})_{3}\right]_{3}$, was reported by Howard and Woodward in 1971 from the thermolysis of $\left(\mathrm{Me}_{3} \mathrm{Ge}\right)_{2} \mathrm{Ru}(\mathrm{CO})_{4}$, which in turn was synthesized from the reaction of $\mathrm{Ru}_{3}(\mathrm{CO})_{12}$ with $\mathrm{Me}_{3} \mathrm{GeH}$ [15]. Since that initial report, the related ruthenium-germanium compounds $\quad\left[\left(\mu_{3}-\mathrm{Ge}\left\{\mathrm{Ru}(\mathrm{CO})_{2}\left(\eta^{5}-\mathrm{C}_{5} \mathrm{Me}_{4} \mathrm{H}\right)\right\}\right)\right]_{2} \mathrm{Ru}_{3}(\mathrm{CO})_{9} \quad$ and $\quad \mathrm{Ru}_{3}\{\mu-$ $\left.\mathrm{Ge}\left(\mathrm{NCH}_{2} \mathrm{CMe}_{3}\right)_{2} \mathrm{C}_{6} \mathrm{H}_{4}\right\}_{3}(\mathrm{CO})_{9}$ have been isolated from the thermolysis reaction of $\mathrm{Ru}_{3}(\mathrm{CO})_{12}$ with $\mathrm{C}_{5} \mathrm{Me}_{4} \mathrm{HMe}_{2} \mathrm{GeGeMe}_{2} \mathrm{C}_{5} \mathrm{Me}_{4} \mathrm{H}$ and 1,3-bis(neo-pentyl)-2-germabenzimidazol-2-ylidene, respectively $[16,17]$. The former cluster exhibits a trigonal-bipyramidal $\mathrm{Ge}_{2} \mathrm{Ru}_{3}$ polyhedral frame while the latter cluster reveals a triangular $\mathrm{Ru}_{3}$ core where each metallic edge is bridged by a germylene moiety.

Studies have shown that the incorporation of organogermanium/organotin moieties into the coordination sphere of a metal carbonyl cluster by oxidative addition of the corresponding hydrides $\mathrm{R}_{3} \mathrm{EH}$ (where $\mathrm{E}=\mathrm{Ge}, \mathrm{Sn} ; \mathrm{R}=$ alkyl, aryl) remains a convenient and 
widely used method for the synthesis of new Group 14-substituted metal clusters [6, 7, 2124]. Recently, we reported the preparation of new $\mathrm{Os}_{3} \mathrm{Sn}_{\mathrm{x}}$ and $\mathrm{Os}_{3} \mathrm{Ge}_{\mathrm{x}}$ clusters from the reactions of $\mathrm{Os}_{3}(\mathrm{CO})_{10}(\mu-\mathrm{dppm})$ and the related ligand-activated cluster $\mathrm{Os}_{3}(\mathrm{CO})_{8}\left[\mu_{3}-\right.$ $\left.\mathrm{Ph}_{2} \mathrm{PCH}_{2} \mathrm{P}(\mathrm{Ph}) \mathrm{C}_{6} \mathrm{H}_{4}\right](\mu-\mathrm{H})$ with $\mathrm{Ph}_{3} \mathrm{SnH}$ [6] and $\mathrm{Ph}_{3} \mathrm{GeH}$ [7]. This work reinforces the view that cluster degradation, which is frequently observed during the reaction between metal carbonyl clusters and organotin/organogermanium hydrides or other tin/germanium sources, may be significantly inhibited by the presence of a bridging dppm ligand that can impart additional stabilization to the metallic polyhedron by the ability to hold contiguous metal centers together. Accordingly, we have examined the functionalization of $\operatorname{Ru}_{3}(\mathrm{CO})_{10}(\mu-$ dppm) with $\mathrm{Ph}_{3} \mathrm{GeH}$ as a route to new $\mathrm{Ru}_{3} \mathrm{Ge}_{\mathrm{x}}$ clusters that can serve as precursors for alloy and nanoparticle catalysts. Herein we report on our results of the synthesis and characterization of new germanium-containing $\mathrm{Ru}_{3}(\mu-\mathrm{dppm})$ clusters.

\section{Results and discussion}

\subsection{Reaction of $\mathrm{Ru}_{3}(\mathrm{CO})_{10}(\mu-\mathrm{dppm})$ with $\mathrm{Ph}{ }_{3} \mathrm{GeH}$ through $\mathrm{Ge}-\mathrm{H}$ bond activation}

The $\mathrm{Me}_{3} \mathrm{NO}$-initiated reaction between $\mathrm{Ru}_{3}(\mathrm{CO})_{10}\left(\mu\right.$-dppm) and $\mathrm{Ph}_{3} \mathrm{GeH}$ at room temperature gives $\mathrm{Ru}_{3}(\mathrm{CO})_{9}\left(\mathrm{GePh}_{3}\right)(\mu$-dppm)( $\mu-\mathrm{H})$ (1) and $\mathrm{Ru}_{3}(\mathrm{CO})_{8}\left(\mathrm{GePh}_{3}\right)_{2}(\mu$-dppm $)(\mu-$ $\mathrm{H})_{2}$ (2) in 31 and 19\% yield, respectively, after chromatographic separation and recrystallization (Scheme 1). In a separate experiment, 1 was shown to react with $\mathrm{Ph}_{3} \mathrm{GeH}$ under similar reaction conditions to afford $\mathbf{2}$, thus confirming the sequential formation of $\mathbf{1}$ and 2 through an oxidative-addition process of the $\mathrm{Ge}-\mathrm{H}$ bond of the germanium reagent. Both $\mathrm{Ru}_{3}$ products are new and they have been characterized by analytical and spectroscopic methods, and the molecular structure of $\mathbf{1}$ was determined by single crystal X-ray diffraction analysis.
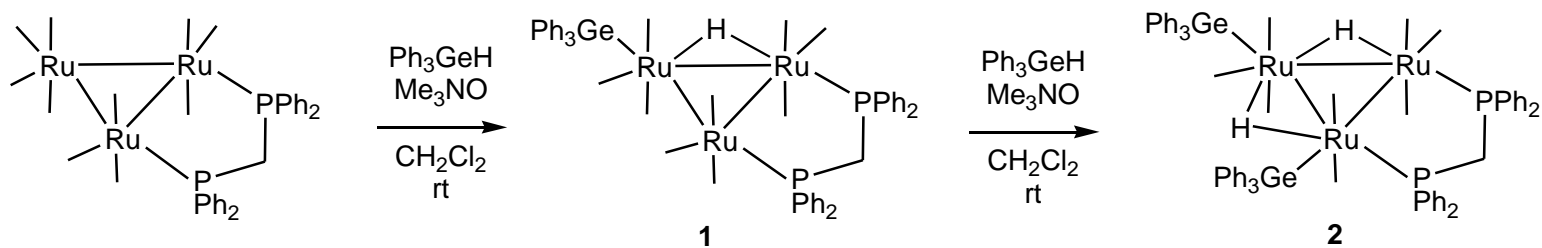

Scheme 1. Reaction of $\mathrm{Ru}_{3}(\mathrm{CO})_{10}\left(\mu\right.$-dppm) with $\mathrm{Ph}_{3} \mathrm{GeH}$. 
An ORTEP diagram of the molecular structure of $\mathbf{1}$ is depicted in Fig. 1, and selected bond distances and angles are presented in the figure caption. The molecule contains an a triruthenium core with three formal $\mathrm{Ru}-\mathrm{Ru}$ single bonds $[\mathrm{Ru}(1)-\mathrm{Ru}(2) 2.8441(3), \mathrm{Ru}(2)-$ $\operatorname{Ru}(3) 2.8813(3)$ and $\operatorname{Ru}(1)-\operatorname{Ru}(3) 3.0148(3) \AA]$ that exhibit a mean distance of $2.9134 \AA$. Nine terminal carbonyl groups are noted, of which three are equally distributed at each ruthenium center. The dppm and hydride ligands bridge adjacent metallic edges, and the $\mathrm{Ph}_{3} \mathrm{Ge}$ moiety is situated syn to the hydride at the phosphine-free ruthenium center. The hydride ligand was located from a Fourier map and found to bridge the longest of the three ruthenium-ruthenium edges defined by the $\mathrm{Ru}(1)-\mathrm{Ru}(3)$ distance. The triphenylgermanium ligand is coordinated to $\mathrm{Ru}(1)$, occupying an equatorial site as expected, and the $\mathrm{Ru}(1)-\mathrm{Ge}(1)$ bond distance of 2.5054(3) $\AA$ is comparable to the terminally coordinated $\mathrm{GeMe}_{3}$ ligands in $\mathrm{C}_{8} \mathrm{H}_{6}\left[(\mathrm{CO})_{2} \mathrm{Ru}\left(\mathrm{GeMe}_{3}\right)\right]_{2}$ (mean $2.487 \AA$ ) [25]. The gross structural features of 1 are similar to those displayed in the related trimetallic clusters $\left[\mathrm{Ru}_{3}(\mathrm{CO})_{9}\left(\mathrm{SiPh}_{3}\right)(\mu-\mathrm{dppm})(\mu-\mathrm{H})\right][26]$ and $\left[\mathrm{Os}_{3}(\mathrm{CO})_{9}\left(\mathrm{GePh}_{3}\right)(\mu-\mathrm{dppm})(\mu-\mathrm{H})\right][7]$ reported by us. The solution spectroscopic data for 1 indicate that the solid-state structure persists in solution. The ${ }^{1} \mathrm{H}$ NMR spectrum displays a upfield doublet at $-18.25 \mathrm{ppm}(\mathrm{J} 30.0 \mathrm{~Hz})$ due to the bridging hydride and a virtual triplet at $4.43 \mathrm{ppm}(\mathrm{J} 10.0 \mathrm{~Hz})$, integrating for two protons, that is attributed to the methylene protons of the dppm ligand. The aryl hydrogens appear as three sets of multiplets from 7.26-7.54 ppm. The two ${ }^{31} \mathrm{P}$ doublets centered at 9.0 and $7.3 \mathrm{ppm}\left(\mathrm{J}_{\mathrm{PP}} 52.0 \mathrm{~Hz}\right)$ in the ${ }^{31} \mathrm{P}\left\{{ }^{1} \mathrm{H}\right\} \mathrm{NMR}$ spectrum are consistent with the non-equivalent phosphorus atoms of the dppm ligand.

\section{Place Figure 1 Here}

The preferred disposition of the $\mathrm{Ph}_{3} \mathrm{Ge}$ ligand relative to the edge-bridging hydride was examined by electronic structure calculations. Here we optimized the structure of 1 (A1) and the corresponding stereoisomer where the $\mathrm{Ph}_{3} \mathrm{Ge}$ ligand is situated at the alternative equatorial site distal to the hydride (A2). These structures are depicted in Fig. 2 and $\mathbf{A 1}$ is computed to be $3.8 \mathrm{kcal} / \mathrm{mol}(\Delta \mathrm{G})$ more stable than A2. This locus preference for the ancillary $\mathrm{Ph}_{3} \mathrm{Ge}$ ligand follows that recently computed by us for the corresponding $\mathrm{Ph}_{3} \mathrm{Sn}$ derivative $\left[\mathrm{Ru}_{3}(\mathrm{CO})_{9}\left(\mathrm{SnPh}_{3}\right)(\mu-\mathrm{dppm})(\mu-\mathrm{H})\right]$ [27], whose stereoisomers differ in energy by $2.2 \mathrm{kcal} / \mathrm{mol}$ in favor of the syn disposed $\mathrm{Ph}_{3} \mathrm{Sn}$ and hydride groups.

\section{Place Figure 2 Here}


Attempts to grow single crystals of cluster 2 for X-ray diffraction analysis were met with failure, yielding either amorphous or highly disordered crystalline material. Therefore, $\mathbf{2}$ was characterizedby a combination of analytical and spectroscopic methods. The IR spectrum of 2 exhibits six carbonyl absorptions over the wave number range 2061 to $1971 \mathrm{~cm}^{-1}$, indicating that all of the carbonyl groups are terminally bound in the cluster. The FAB mass spectrum displays a molecular ion at $\mathrm{m} / \mathrm{z}, 1522$ in addition to signature ions due to sequential loss of seven carbonyls, all of which are consistent with the formulated structure in Scheme 1.

The ${ }^{1} \mathrm{H}$ and ${ }^{31} \mathrm{P}$ NMR data recorded for 2 provide evidence for hydride fluxionality at room temperature. The ${ }^{1} \mathrm{H}$ NMR spectrum revealed a pair of broad hydride resonances and the ${ }^{31} \mathrm{P}$ NMR spectrum exhibited similar behavior, making an unequivocal structural and spectral assignment problematic. Spectral clarity was achieved when $\mathbf{2}$ was examined by VT NMR over the temperature range 298-233 K, and these data are shown in Figs. 3 and 4. Lowering the temperature to $233 \mathrm{~K}$ led to a sharpening of the hydride and the phosphine resonances in their respective spectra as the limiting spectrum is reached. The observation of inequivalent hydride doublets and distinct ${ }^{31} \mathrm{P}$ doublets at $233 \mathrm{~K}$ rules out a structure that contains an edge-bridging hydride at the dppm-ligated Ru-Ru edge as an energy minimum. While the structure of $\mathbf{2}$ is consistent with that depicted in Scheme 1, alternative structures may be reconciled with the limiting NMR data and cannot be eliminated from consideration at this juncture.

\section{Place Figures 3 and 4 Here}

The fluxional behavior displayed by 2 likely originates from a rapid hydride movement between adjacent $\mathrm{Ru}-\mathrm{Ru}$ bonds or a turnstile-type rotation that promotes an exchange of the $\mathrm{GePh}_{3}$ ligand between the two equatorial sites at the $\mathrm{Ru}(\mathrm{CO})_{3}\left(\mathrm{GePh}_{3}\right)$ moiety. The dynamic NMR properties in related triphenylsilane-substituted clusters have been attributed to a variant of the latter exchange process [28]. Scheme 2 illustrates the possible exchange mechanisms. 

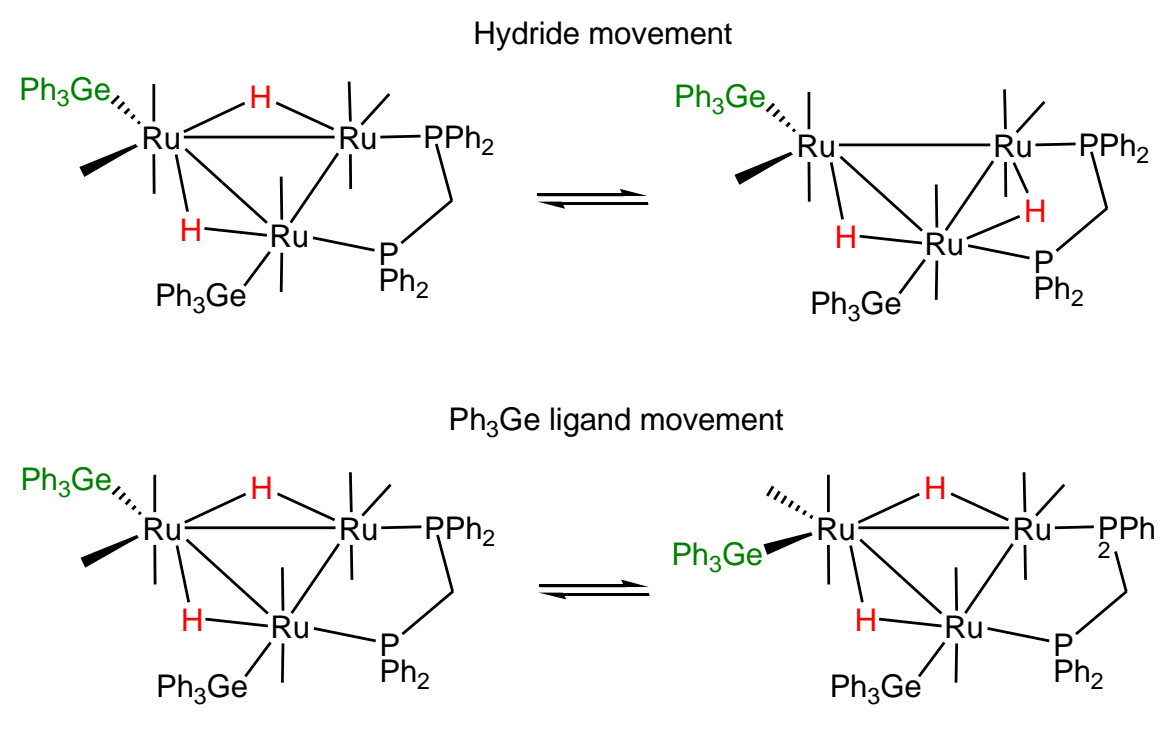

Scheme 2. Proposed fluxional processes in $\mathrm{Ru}_{3}(\mathrm{CO})_{8}\left(\mathrm{GePh}_{3}\right)_{2}(\mu$-dppm $)(\mu-\mathrm{H})_{2}(\mathbf{2})$.

To gain a better understanding of the NMR behavior and to establish the preferred ligand disposition in 2, we next performed a series of DFT calculations. We successfully optimized structures of six dihydrides (Fig. 5) whose relative energies are displayed in Fig. 6. Structures B1-B5 contain inequivalent hydrides and a nonsymmetrical dppm ligand and could, in theory, give NMR spectral data consistent with that recorded in solution. Of these five structures, species B1 is computed as the ground-state minimum. The second most stable structure is $\mathbf{B 2}$ which lies $1.9 \mathrm{kcal} / \mathrm{mol}$ above B1. The main difference between $\mathbf{B 1}$ and $\mathbf{B 2}$ is the migration of one of the hydrides to the dppm-bridged Ru-Ru bond. Species B3 contains a bridging dppm ligand that is bound at adjacent axial sites relative to $\mathbf{B} \mathbf{1}$ whose dppm ligand occupies adjacent equatorial sites. The energetic penalty associated with such a dppm conformational change is $9.2 \mathrm{kcal} / \mathrm{mol}$ and is in keeping with earlier calculations by us on ligand fluxional processes in $\mathrm{Ru}_{3}$ and $\mathrm{Os}_{3}$ clusters [29]. Migration of the $\mathrm{Ph}_{3} \mathrm{Ge}$ moiety from its equatorial site in $\mathbf{B} 1$ to the other equatorial site at the $\mathrm{Ru}(\mathrm{CO})_{3}\left(\mathrm{GePh}_{3}\right)$ vertex furnishes B4, and the unfavorable disposition of syn $\mathrm{Ph}_{3} \mathrm{Ge}$ ligands is the principal source of the computed $11.0 \mathrm{kcal} / \mathrm{mol}$ destabilization. Species $\mathbf{B 5}$ underscores the preference with respect to hydride migration to the dppm-bridged $\mathrm{Ru}-\mathrm{Ru}$ bond. Whereas $\mathbf{B 2}$ is only marginally less stable than B1, migration of the second hydride in B1 to the dppm-bridged Ru-Ru bond is particularly unfavorable by $16.4 \mathrm{kcal} / \mathrm{mol}$. While inconsistent with the limiting NMR spectral data, we examined the symmetrical species B6 that contains a mirror plane of symmetry orthogonal to the dppm-bridged Ru-Ru bond. Transposition of the $\mathrm{Ph}_{3} \mathrm{Ge}$ moiety in $\mathbf{B} \mathbf{1}$ to the 
adjacent equatorial site at the $\mathrm{Ru}(\mathrm{CO})_{3} \mathrm{P}$ moiety is extremely unfavorable based on the 31.4 $\mathrm{kcal} / \mathrm{mol}$ increase in energy.

\section{Place Figures 5 and 6 Here}

The fluxional behavior recorded in the ${ }^{1} \mathrm{H}$ and ${ }^{31} \mathrm{P}$ NMR spectra of 2 is best explained by the hydride movement process depicted in Scheme 2. The $\Delta \mathrm{G}^{\neq}$value for the hydride fluxionality is estimated as $13.0 \mathrm{kcal} / \mathrm{mol}$ based on the frequency of separation of the hydride resonances in the slow-exchange spectrum and a coalescence temperature of $c a .300 \mathrm{~K}$. Rapid hydride oscillation between species B1 and B2 would furnish broadened hydride and phosphine resonances, and we subsequently confirmed TSB1B2 as a viable transition structure for this exchange. Fig. 7 shows this process, and the computed energy of activation $\left(\Delta \mathrm{G}^{\ddagger}=10.8 \mathrm{kcal} / \mathrm{mol}\right)$ fits with the experimental data that support the formation of $\mathbf{B} \mathbf{1}$ as the limiting structure at $233 \mathrm{~K}$. The migration of the edge-bridging hydride to an interstitial site of the triangular cluster furnishes the transition structure TSB1B2, and continued transit of the hydride affords the edge-bridged hydride B2. Our DFT data for the hydride shuttle between adjacent $\mathrm{Ru}-\mathrm{Ru}$ bonds in the isomers of $\mathbf{B 1}$ and $\mathbf{B 2}$ are consistent with earlier proposed hydride migration schemes in other trimetallic clusters [30].

\section{Place Figure 7 Here}

\subsection{Thermolysis of 1: $G e-C, P-C, C-H$ and $R u-R u$ bond cleavage}

The cleavage of a phenyl group(s) from the heteroatom in $\mathrm{Ph}_{3} \mathrm{E}$ derived ligands is an important transformation that can afford edge-bridging and face-capping $\mathrm{Ph}_{2} \mathrm{E}$ or $\mathrm{PhE}(\mathrm{E}=$ $\mathrm{Sn}, \mathrm{Ge})$ fragments $[21 \mathrm{~b}, \mathrm{~g}]$. For example, the $\mathrm{SnPh}_{3}$ ligand in $\mathrm{Ru}_{5}(\mathrm{CO})_{11}\left(\mathrm{C}_{6} \mathrm{H}_{6}\right)\left(\mathrm{SnPh}_{3}\right)(\mu-$ $\mathrm{H})\left(\mu_{5}-\mathrm{C}\right)$ undergoes multiple aryl cleavages to yield $\mathrm{Ru}_{5}(\mathrm{CO})_{11}\left(\mathrm{C}_{6} \mathrm{H}_{6}\right)\left(\mu_{4}-\mathrm{SnPh}\right)(\mu-\mathrm{H})\left(\mu_{3}-\right.$ $\mathrm{CPh}$ ), which contains a quadruply bridging PhSn ligand [21b]. Based on this observation, we investigated the thermal stability of $\mathbf{1}$ and the propensity of the $\mathrm{Ph}_{3} \mathrm{Ge}$ ligand to undergo cleavage reactions at elevated temperatures. Refluxing $\mathbf{1}$ in THF furnished the diruthenium complex $\mathrm{Ru}_{2}(\mathrm{CO})_{6}\left(\mu-\mathrm{GePh}_{2}\right)(\mu-\mathrm{dppm})(3)$ in $44 \%$ isolated yield. Complex 3 is the major product, which derives from cleavage of the $\mathrm{Ge}-\mathrm{C}$ (phenyl) and $\mathrm{Ru}-\mathrm{Ru}$ bonds. The two minor products isolated from the thermolysis reaction are the triruthenium clusters $\operatorname{Ru}_{3}(C O)_{7}(\mu-$ 
$\mathrm{CO})\left(\mathrm{GePh}_{3}\right)\left\{\mu_{3}-\mathrm{PhPCH}_{2} \mathrm{P}(\mathrm{Ph}) \mathrm{C}_{6} \mathrm{H}_{4}\right\}(\mu-\mathrm{H}) \quad$ (4) (8\%) and the previously reported $\mathrm{Ru}_{3}(\mathrm{CO})_{9}\left(\mu_{3}-\mathrm{Ph}_{2} \mathrm{PCH}_{2} \mathrm{PPh}\right)(\mu-\mathrm{H}) \quad$ (5) [31], whose identity was established by spectral comparison against an independently prepared sample of $\mathbf{5}$. These thermolysis products are shown in Scheme 3. While the dppm ligand remains intact in $\mathbf{3}$, it undergoes both $\mathrm{P}-\mathrm{C}$ and $\mathrm{C}-\mathrm{H}$ bond activation en route to $\mathbf{4}$ and $\mathbf{5}$. The new compounds $\mathbf{3}$ and $\mathbf{4}$ have been characterized by analytical and spectroscopic methods, and the molecular structure of $\mathbf{3}$ was established by X-ray diffraction analysis.

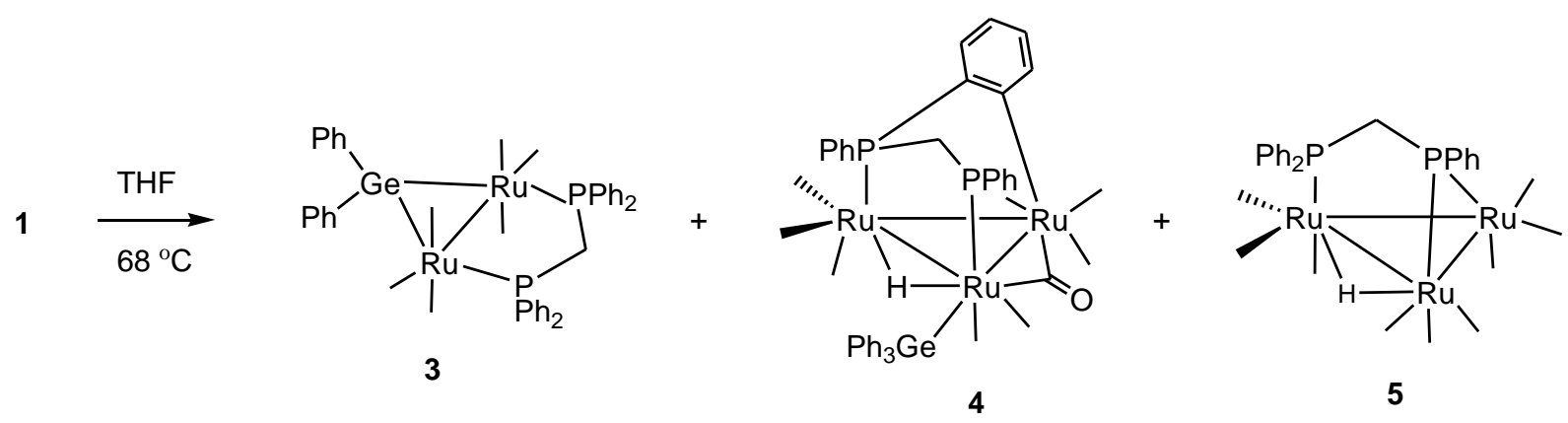

Scheme 3. Thermolysis behavior of $\mathbf{1}$.

The ORTEP diagram of the solid-state molecular structure of $\mathbf{3}$ is shown in Fig. 8, and selected bond distances and angles are quoted in the figure caption. Complex $\mathbf{3}$ is a diruthenium complex whose ruthenium atoms are bridged by dppm and diphenylgermanium ligands. Three terminal carbonyl ligands are coordinated to each metal center. The diphenylgermylene moiety bridges the ruthenium-ruthenium edge in a symmetric fashion, with a mean Ru-Ge bond distance of $2.4944 \AA[\mathrm{Ru}(1)-\mathrm{Ge}(1) 2.5007(8)$ and $\mathrm{Ru}(2)-\mathrm{Ge}(1)$ 2.4881(8) $\mathrm{A}$ ]. The edge-bridging $\mathrm{Ph}_{2} \mathrm{Ge}$ moiety displays a Ru-Ge-Ru angle of 71.91(2) ${ }^{\mathrm{o}}$, and the germanium atom is coplanar with the two distally oriented phosphine moieties of the dppm ligand. The Ru-Ge bond distances are very similar to those distances reported for $\mathrm{Ru}_{3}(\mathrm{CO})_{9}\left(\mu-\mathrm{GeMe}_{2}\right)_{3}$ [Ru-Ge range 2.482(11)-2.500(12) $\AA$ ] [15]. The Ru-Ru distance in 3 of 2.9293(6) $\AA$ is consistent with its Ru-Ru single-bond designation and is in agreement with the reported $\mathrm{Ru}$-Ru distance of 2.9072(8) $\AA$ in $\mathrm{Ru}_{2}(\mathrm{CO})_{6}\left(\mu-\mathrm{SiTo}_{2}\right)(\mu$-dppm), which was obtained from the reaction of $\mathrm{Ru}_{3}(\mathrm{CO})_{10}(\mu-\mathrm{dppm})$ with $\mathrm{Tol}_{2} \mathrm{SiH}_{2}$ [32]. The overall architecture of $\mathbf{3}$ is similar to the $\mu$-silylene analog $\mathrm{Ru}_{2}(\mathrm{CO})_{6}\left(\mu-\mathrm{SiTol}_{2}\right)(\mu$-dppm) [32].

\section{Place Figure 8 Here}


The solution spectroscopic data of $\mathbf{3}$ are consistent with its solid-state structure. The infrared spectrum shows four carbonyl absorptions from 2062 to $1957 \mathrm{~cm}^{-1}$ and confirms the presence of only terminal carbonyl ligands. The ${ }^{1} \mathrm{H}$ NMR spectrum displays a triplet at 3.93 ppm $(\mathrm{J} 10.0 \mathrm{~Hz})$ assignable to the methylene protons of the dppm ligand, along with resonances from 7.18-7.66 ppm for the phenyl protons associated with the dppm and diphenylgermylene ligands. The ${ }^{31} \mathrm{P}\left\{{ }^{1} \mathrm{H}\right\}$ NMR spectrum displays a singlet at $31.3 \mathrm{ppm}$ for the two equivalent phosphorus nuclei of the dppm in keeping with the idealized $\mathrm{C}_{2 v}$ exhibited by the product.

Repeated attempts to grow single crystals of $\mathbf{4}$ for X-ray diffraction analysis were unsuccessful, and we had to rely on characterization by analytical and spectroscopic data only. Fortunately, several closely related silyl analogs have been reported, and we were able to reconcile the recorded data for $\mathbf{4}$ against the silyl congeners. The IR spectrum recorded for 4 closely matches the IR data for a series of $\mathrm{Ru}_{3}(\mathrm{CO})_{7}(\mu-\mathrm{CO})\left(\mathrm{SiR}_{3}\right)(\mu-\mathrm{H})\left\{\mu_{3}-\right.$ $\left.\mathrm{PhPCH}_{2} \mathrm{P}(\mathrm{Ph}) \mathrm{C}_{6} \mathrm{H}_{4}\right\}$ clusters [26]. The spectrum exhibits seven carbonyl absorptions, of which six appear from 2079 to $1932 \mathrm{~cm}^{-1}$ and one a weak absorption appears at $1865 \mathrm{~cm}^{-1}$. The former represent terminal $v(\mathrm{CO})$ bands while the latter is assigned to the lone bridging carbonyl associated with the $\mathrm{Ru}-\mathrm{Ru}$ bond also bound by the phosphido moiety. Diagnostic ${ }^{1} \mathrm{H}$ resonances include the upfield multiplet at $-16.10 \mathrm{ppm}$ due to the bridging hydride ligand and the two multiplets centered at 4.38 and $3.77 \mathrm{ppm}$ that are attributed to the methylene protons of the diphosphine ligand. The ${ }^{31} \mathrm{P}\left\{{ }^{1} \mathrm{H}\right\}$ NMR spectrum exhibits two doublets at 88.0 and $0.83 \mathrm{ppm}(\mathrm{J} 82.0 \mathrm{~Hz})$ due to the phosphorus atoms of the diphosphine ligand, the former is assigned to the bridging phosphido moiety. The FAB mass spectrum displays a molecular ion at $\mathrm{m} / z .1139$ together with further ions due to sequential loss of eight carbonyls, which is consistent with the formulated structure.

\subsection{Thermolysis of 2: Ge-C and $R u-R u$ bond cleavage}

The stability of $\mathbf{2}$ in refluxing THF was also examined as it would allow us to compare the product distribution vis-à-vis the thermolysis reaction of $\mathbf{1}$, which furnishes $\mathbf{3}$ via cleavage of the Ge-C and Ru-Ru bonds and gives $\mathbf{4}$ via activation of the P-C and C-H bonds of the dppm ligand. Thermolysis of $\mathbf{2}$ affords the dinuclear complex $\mathbf{3}$ as the major product $(31 \%)$ and the hydroxyl-bridged dihydride cluster $\mathrm{Ru}_{3}(\mathrm{CO})_{6}\left(\mathrm{GePh}_{3}\right)(\mu-\mathrm{OH})(\mu$-dppm $)(\mu-\mathrm{H})_{2}$ 
(6) in $16 \%$ yield as the minor product. The reaction is illustrated in Scheme 4. The yield of 6 could be increased to $25 \%$ by the addition of water (one drop) to the reaction before thermolysis, and this response to added water supports the source of the hydroxyl ligand in $\mathbf{6}$ originating from residual water present in the solvent. The formation of $\mathbf{6}$ was significantly reduced $(<3 \%)$ when rigorously dried THF was employed, but even under these conditions trace amounts of $\mathbf{6}$ were produced, suggesting the extreme sensitivity of this reaction to adventitious moisture.

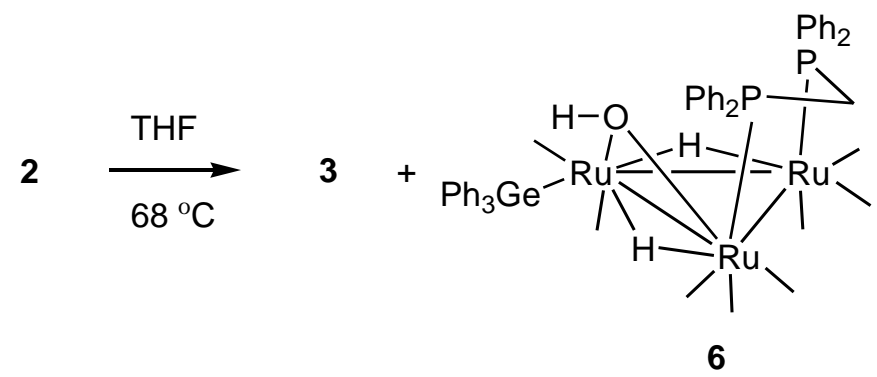

Scheme 4. Thermolysis of 2 in refluxing THF.

The new cluster $\mathbf{6}$ has been characterized by a combination of combustion, spectroscopic, and X-ray diffraction analyses. An ORTEP drawing of the molecular structure of $\mathbf{6}$ is shown in Fig. 9, whose caption lists selected bond distances and angles. The molecular structure consists of a ruthenium triangle that exhibits three $\mathrm{Ru}-\mathrm{Ru}$ bonds that range from 2.7775(3) $\AA[R u(1)-R u(2)]$ to 3.1051(3) $\AA[R u(2)-R u(3)]$ and displays a mean $R u-R u$ bond distance of $2.9113 \AA$. Note in the coordination sphere are seven terminal carbonyls, two bridging hydrides, one bridging hydroxyl group, an $\eta^{1} \mathrm{Ph}_{3} \mathrm{Ge}$ moiety, and a bridging dppm ligand. The edge-bridging hydroxy ligand spans the short $\mathrm{Ru}(1)-\mathrm{Ru}(2)$ bond that also serves as the site for one of the hydrides. The $\mathrm{Ru}-\mathrm{O}$ bond distances are comparable to those distances reported for the triruthenium clusters $\mathrm{Ru}_{3}(\mathrm{CO})_{8}(\mu-\mathrm{BINAP})(\mu-\mathrm{OH})_{2}[2.118(13)-$ 2.102(13) $\AA$ ] [33] and $\mathrm{Ru}_{3}(\mathrm{CO})_{8}(\mu-\mathrm{dppf})(\mu-\mathrm{OH})_{2}$ [2.111(3)-2.135(3) $\AA$ ] [34]. The second hydride bridges the long $\mathrm{Ru}(2)-\mathrm{Ru}(3)$ edge while the third edge defined by the $\mathrm{Ru}(1)-\mathrm{Ru}(3)$ bond thatis ligated by the axially disposed dppm ligand. The triphenylgermanium ligand is bonded to $\mathrm{Ru}(2)$, occupying an equatorial coordination site, and the $\mathrm{Ru}-\mathrm{Ge}$ bond distance of 2.4654(3) $\AA$ is slightly shorter than the Ru-Ge bond distance in $\mathbf{1}$.

\section{Place Figure 9 Here}


The solution spectroscopic data of $\mathbf{6}$ indicate that the solid-state structure persists in solution. The ${ }^{1} \mathrm{H}$ NMR spectrum shows two upfield doublets at $-12.3(\mathrm{~J} 17.2 \mathrm{~Hz})$ and -11.8 ppm $(\mathrm{J} 7.6 \mathrm{~Hz})$ due to hydrides whose splitting derives from the phosphine moiety geminally situated to the respective hydride $\left({ }^{2} \mathrm{~J}_{\mathrm{PH}}\right)$. The ${ }^{1} \mathrm{H}$ two multiplets at 4.50 and $3.50 \mathrm{ppm}$ are assigned to the methylene protons of dppm ligand, and the doublet at $0.27\left({ }^{3} \mathrm{~J}_{\mathrm{P}-\mathrm{H}} 4.2 \mathrm{~Hz}\right) \mathrm{ppm}$ was verified as the hydroxyl proton based on its integral ratio and response to added $\mathrm{D}_{2} \mathrm{O}$. The ${ }^{31} \mathrm{P}\left\{{ }^{1} \mathrm{H}\right\}$ NMR spectrum displays two doublets at 29.1 and $34.0 \mathrm{ppm}(\mathrm{J} 67.0 \mathrm{~Hz})$ for the phosphorus atoms of dppm ligands in accord with the solid-state structure.

We have also investigated the structure of $\mathbf{6}$ relative to the stereochemistry of the hydride and hydroxyl groups that span the common Ru-Ru edge. DFT optimization of 6 gives species C1, whose structure is depicted in Fig. 10 and which closely resembles the solid-state structure. The hydrogen attached to the hydroxyl oxygen occupies a small cavity in the coordination sphere of the cluster that is created by the equatorial $\mathrm{Ph}_{3} \mathrm{Ge}$ and axial dppm ligands. The stereoisomer $\mathbf{C 2}$ is similar to $\mathbf{C 1}$ except for the exchange of the hydroxyl and hydride groups across the shared Ru-Ru bond. $\mathbf{C 2}$ is $5.9 \mathrm{kcal} / \mathrm{mol}$ less stable than $\mathbf{C 1}$, and the chief perturbation lies in the unfavorable van der Waals contact that exists between the hydroxyl hydrogen atom and one of the phenyl groups from the $\mathrm{Ph}_{3} \mathrm{Ge}$ ligand that is situated below the metallic plane.

\section{Place Figure 10 Here}

\section{Conclusions}

In summary, new ruthenium-germanium compounds have been prepared from the functionalization of $\mathrm{Ru}_{3}(\mathrm{CO})_{10}(\mu-\mathrm{dppm})$ with $\mathrm{Ph}_{3} \mathrm{GeH}$. Depending on the reactions conditions, the $\mathrm{Ru}: \mathrm{Ge}$ stoichiometry may be controlled to give $\mathrm{Ru}_{3}(\mathrm{CO})_{9}\left(\mathrm{GePh}_{3}\right)(\mu$-dppm $)(\mu$ H) (1) and $\mathrm{Ru}_{3}(\mathrm{CO})_{8}\left(\mathrm{GePh}_{3}\right)_{2}(\mu-\mathrm{dppm})(\mu-\mathrm{H})_{2}(2)$ through stepwise oxidative-addition of one and two $\mathrm{Ge}-\mathrm{H}$ bonds, respectively. The thermal behavior of these new clusters has been examined, and the diruthenium complex $\mathrm{Ru}_{2}(\mathrm{CO})_{6}\left(\mu-\mathrm{GePh}_{2}\right)(\mu-\mathrm{dppm})(3)$ has been found as the major product in the thermolysis of both $\mathbf{1}$ and $\mathbf{2}$. The formation of the $\mathrm{GePh}_{2}$ ligand in $\mathbf{3}$ confirms the inherent lability of a $\mathrm{Ph}-\mathrm{Ge}$ bond in the ancillary $\mathrm{Ph}_{3} \mathrm{Ge}$ ligand to undergo cleavage at elevated temperature. The triruthenium clusters $\mathrm{Ru}_{3}(\mathrm{CO})_{7}(\mu-\mathrm{CO})\left(\mathrm{GePh}_{3}\right)\left\{\mu_{3}-\right.$ 
$\left.\mathrm{PhPCH}_{2} \mathrm{P}(\mathrm{Ph}) \mathrm{C}_{6} \mathrm{H}_{4}\right\}(\mu-\mathrm{H})(4)$ and $\mathrm{Ru}_{3}(\mathrm{CO})_{9}\left(\mu_{3}-\mathrm{Ph}_{2} \mathrm{PCH}_{2} \mathrm{PPh}\right)(\mu-\mathrm{H})(5)$ [31] were isolated as minor products in these reactions. Trace moisture is effectively captured during thermolysis cycle and affords the hydroxyl-bridged dihydride $\mathrm{Ru}_{3}(\mathrm{CO})_{6}\left(\mathrm{GePh}_{3}\right)(\mu-\mathrm{OH})(\mu$-dppm $)(\mu-\mathrm{H})_{2}$ (6). DFT calculations have been performed, and the nature of the ground-state structures found to coincide with the X-ray diffraction structures that were determined.

\section{Experimental section}

\subsection{General remarks}

All reactions were carried under an inert atmosphere of nitrogen using standard Schlenk techniques unless otherwise stated. Reagent grade solvents were dried by the standard procedures and were freshly distilledbefore use. $\mathrm{Ru}_{3}(\mathrm{CO})_{12}$ was purchased from Strem Chemical Inc. and used without further purification. Bis(diphenylphosphino)methane (dppm) and $\mathrm{Ph}_{3} \mathrm{GeH}$ were purchased from Acros Chemicals and used as received. $\mathrm{Ru}_{3}(\mathrm{CO})_{10}\left(\mu\right.$-dppm)was prepared according to the published procedure [35]. ${ }^{1} \mathrm{H}$ and ${ }^{31} \mathrm{P}\left\{{ }^{1} \mathrm{H}\right\}$ NMR spectra were recorded on an INOVA-500instrument, and IR spectra were recorded on a Shimadzu FTIR Prestige 21 spectrophotometer. Elemental analyses were performed by the Microanalytical Laboratory of Wazed Miah Science Research Centre at Jahangirnagar University. All products were separated in the air using TLC plates coated with $0.25 \mathrm{~mm}$ of silica gel ( $\mathrm{HF}_{254}$-type 60, E. Merck, Germany).

\subsection{Reaction of $\mathrm{Ru}_{3}(\mathrm{CO})_{10}(\mu-d p p m)$ with $\mathrm{Ph}_{3} \mathrm{GeH}$}

A $\mathrm{CH}_{2} \mathrm{Cl}_{2}$ solution $(10 \mathrm{~mL})$ of $\mathrm{Me}_{3} \mathrm{NO}(12 \mathrm{mg}, 0.16 \mathrm{mmol})$ was added to a $\mathrm{CH}_{2} \mathrm{Cl}_{2}$ solution $(20 \mathrm{~mL})$ containing $\mathrm{Ru}_{3}(\mathrm{CO})_{10}(\mu-\mathrm{dppm})(50 \mathrm{mg}, 0.052 \mathrm{mmol})$ and $\mathrm{Ph}_{3} \mathrm{GeH}(50 \mathrm{mg}$, $0.16 \mathrm{mmol}$ ) using a pressure equalizing dropping funnel over a period of $15 \mathrm{~min}$. The solution was stirred for $2.5 \mathrm{~h}$ at room temperature after the addition was complete, during which time the color of the reaction mixture changed from orange to deep red. The solution was then filtered through a short pad of silica $(4 \mathrm{~cm})$ to remove excess $\mathrm{Me}_{3} \mathrm{NO}$, and the solvent was next removed under reduced pressure. The resulting residue was chromatographically separated by TLC using cyclohexane/ $\mathrm{CH}_{2} \mathrm{Cl}_{2}(7: 3, \mathrm{v} / \mathrm{v})$ as the eluent to give two bands. The faster-moving band afforded $\mathrm{Ru}_{3}(\mathrm{CO})_{9}\left(\mathrm{GePh}_{3}\right)(\mu$-dppm) $(\mu-\mathrm{H})(\mathbf{1})(20$ $\mathrm{mg}, 31 \%)$ as red crystals while the slower band gave $\mathrm{Ru}_{3}(\mathrm{CO})_{8}\left(\mathrm{GePh}_{3}\right)_{2}(\mu$-dppm $)(\mu-\mathrm{H})_{2}(2)$ 
(15 mg, 19\%) as green crystals after recrystallization from hexane/ $\mathrm{CH}_{2} \mathrm{Cl}_{2}$ at $25{ }^{\circ} \mathrm{C}$. Analytical and spectroscopic data for 1: Anal. Calcd for $\mathrm{C}_{52} \mathrm{H}_{38} \mathrm{GeO}_{9} \mathrm{P}_{2} \mathrm{Ru}_{3}: \mathrm{C}, 50.17 ; \mathrm{H}$, 3.08. Found: C, 50.73; H, 3.13\%. IR ( $\left.v \mathrm{CO}, \mathrm{CH}_{2} \mathrm{Cl}_{2}\right)$ : 2080w, 2044s, 2006vs, $1981 \mathrm{sh}, 1968 \mathrm{w}$ $\mathrm{cm}^{-1} .{ }^{1} \mathrm{H} \mathrm{NMR}\left(\mathrm{CDCl}_{3}\right): \delta 7.54(\mathrm{~m}, 6 \mathrm{H}), 7.42(\mathrm{~m}, 12 \mathrm{H}), 7.26(\mathrm{~m}, 17 \mathrm{H}), 4.43(\mathrm{t}, \mathrm{J} 10.0 \mathrm{~Hz}$, 2H), -18.25 (d, J $30.0 \mathrm{~Hz}, 1 \mathrm{H}) .{ }^{31} \mathrm{P}\left\{{ }^{1} \mathrm{H}\right\} \mathrm{NMR}\left(\mathrm{CDCl}_{3}\right): \delta 9.0$ (d, J $\left.52.0 \mathrm{~Hz}, 1 \mathrm{P}\right), 7.3$ (d, J 52.0 $\mathrm{Hz}, 1 \mathrm{P})$. Analytical and spectral data for 2: Anal. Calcd for $\mathrm{C}_{69} \mathrm{H}_{54} \mathrm{Ge}_{2} \mathrm{O}_{8} \mathrm{P}_{2} \mathrm{Ru}_{3}: \mathrm{C}, 54.46 ; \mathrm{H}$, 3.58. Found: C, 55.02; H, 3.66\%. IR ( $v \mathrm{CO}, \mathrm{CH}_{2} \mathrm{Cl}_{2}$ ): 2061w, 2044s, 2032sh, 1996vs, 1971sh, 1930w cm ${ }^{-1} .{ }^{1} \mathrm{H}$ NMR $\left(\mathrm{CDCl}_{3}\right): \delta 7.65(\mathrm{~m}, 12 \mathrm{H}), 7.56-7.37(\mathrm{~m}, 20 \mathrm{H}), 7.32(\mathrm{~m}, 8 \mathrm{H}), 7.28(\mathrm{~m}$, 4H), 7.11-6.88 (m, 6H), $3.14(\mathrm{~m}, 2 \mathrm{H}),-10.70$ (d, J $20.0 \mathrm{~Hz}, 1 \mathrm{H}),-14.56$ (d, J $60.0 \mathrm{~Hz}, 1 \mathrm{H})$. ${ }^{31} \mathrm{P}\left\{{ }^{1} \mathrm{H}\right\} \mathrm{NMR}\left(\mathrm{CDCl}_{3}\right): \delta 14.8(\mathrm{~d}, \mathrm{~J} 28.5 \mathrm{~Hz}, 1 \mathrm{P}),-3.9(\mathrm{~d}, \mathrm{~J} 28.5 \mathrm{~Hz}, 1 \mathrm{P})$. FAB mass: $m / z$ 1522.

\subsection{Conversion of 1 to 2}

To a $\mathrm{CH}_{2} \mathrm{Cl}_{2}$ solution $(20 \mathrm{~mL})$ of $\mathbf{1}(25 \mathrm{mg}, 0.020 \mathrm{mmol})$ and $\mathrm{Ph}_{3} \mathrm{GeH}(7 \mathrm{mg}, 0.023$ mmol) was added a $\mathrm{CH}_{2} \mathrm{Cl}_{2}$ solution $(10 \mathrm{~mL})$ of $\mathrm{Me}_{3} \mathrm{NO}(4 \mathrm{mg}, 0.053 \mathrm{mmol})$ using a pressure equalizing dropping funnel. The mixture was allowed to stir at room temperature for $2.5 \mathrm{~h}$ and then separated by chromatography as described above to give 2 (6 mg, 33\%).

\subsection{Thermolysis of 1}

Cluster 1 (40 mg, $0.032 \mathrm{mmol}$ ) was dissolved in $15 \mathrm{~mL}$ of THF and the solution was heated at reflux for $6 \mathrm{~h}$, during which time the initially red colored solution turned light yellow. The solvent was removed under vacuum and the residue chromatographed by TLC on silica gel. Elution with cyclohexane $/ \mathrm{CH}_{2} \mathrm{Cl}_{2}(7: 3, \mathrm{v} / \mathrm{v})$ developed three bands that yielded the following compounds in order of elution: $\mathrm{Ru}_{3}(\mathrm{CO})_{9}(\mu-\mathrm{H})\left(\mu_{3}-\mathrm{Ph}_{2} \mathrm{PCH}_{2} \mathrm{PPh}\right)(5)$ [31] (2 mg, $7 \%$ ) as yellow crystals, $\mathrm{Ru}_{2}(\mathrm{CO})_{6}\left(\mu-\mathrm{GePh}_{2}\right)(\mu$-dppm) (3) (14 mg, 44\%) as pale yellow crystals, and $\mathrm{Ru}_{3}(\mathrm{CO})_{7}(\mu-\mathrm{CO})\left(\mathrm{GePh}_{3}\right)(\mu-\mathrm{H})\left\{\mu_{3}-\mathrm{PhPCH}_{2} \mathrm{P}(\mathrm{Ph}) \mathrm{C}_{6} \mathrm{H}_{4}\right\}$ (4) (3 mg, 8\%) as red crystals after recrystallization from hexane $/ \mathrm{CH}_{2} \mathrm{Cl}_{2}$ at $25{ }^{\circ} \mathrm{C}$. Analytical and spectroscopic data for 3: Anal. Calcd for $\mathrm{C}_{43} \mathrm{H}_{32} \mathrm{GeO}_{6} \mathrm{P}_{2} \mathrm{Ru}_{2}$ : C, 52.62; H, 3.29. Found: C, 53.06; H, 3.36\%. IR $\left(\nu \mathrm{CO}, \mathrm{CH}_{2} \mathrm{Cl}_{2}\right): 2062 \mathrm{w}, 2025 \mathrm{~s}, 1988 \mathrm{vs}, 1957 \mathrm{~s} \mathrm{~cm}^{-1} .{ }^{1} \mathrm{H} \mathrm{NMR}\left(\mathrm{CDCl}_{3}\right): \delta 7.66(\mathrm{~m}, 4 \mathrm{H})$, $7.44(\mathrm{~m}, 8 \mathrm{H}), 7.37-7.24(\mathrm{~m}, 16 \mathrm{H}), 7.18(\mathrm{~m}, 2 \mathrm{H}), 3.93(\mathrm{t}, \mathrm{J} 10.0 \mathrm{~Hz}, 2 \mathrm{H}) .{ }^{31} \mathrm{P}\left\{{ }^{1} \mathrm{H}\right\} \mathrm{NMR}$ $\left(\mathrm{CDCl}_{3}\right): \delta 31.3$ (s). Analytical and spectroscopic data for 4: Anal. Calcd for 
$\mathrm{C}_{45} \mathrm{H}_{32} \mathrm{GeO}_{8} \mathrm{P}_{2} \mathrm{Ru}_{3}$ : C 47.47; $\mathrm{H}$ 2.83. Found: $\mathrm{C}$, 47.98; $\mathrm{H}$ 2.88\%. IR ( $\left.v \mathrm{CO}, \mathrm{CH}_{2} \mathrm{Cl}_{2}\right)$ : 2079vs, 2044vs, 2028vs, 1993w, 1975w, 1932w, 1865w cm ${ }^{-1} .{ }^{1} \mathrm{H}$ NMR $\left(\mathrm{CDCl}_{3}\right): \delta 7.72(\mathrm{~m}, 2 \mathrm{H}), 7.60$ $(\mathrm{m}, 2 \mathrm{H}), 7.30(\mathrm{~m}, 20 \mathrm{H}), 7.00(\mathrm{~m}, 1 \mathrm{H}), 6.66(\mathrm{~m}, 2 \mathrm{H}), 6.50(\mathrm{~m}, 2 \mathrm{H}), 4.38(\mathrm{~m}, 1 \mathrm{H}), 3.77(\mathrm{~m}$, $1 \mathrm{H}),-16.10(\mathrm{~m}, 1 \mathrm{H}) .{ }^{31} \mathrm{P}\left\{{ }^{1} \mathrm{H}\right\} \mathrm{NMR}\left(\mathrm{CDCl}_{3}\right): \delta 88.0(\mathrm{~d}, \mathrm{~J} 82.0 \mathrm{~Hz}, 1 \mathrm{P}),-0.83(\mathrm{~d}, \mathrm{~J} 82.0 \mathrm{~Hz}$, $1 \mathrm{P})$.

\subsection{Thermolysis of 2}

A THF solution $(15 \mathrm{~mL})$ of $2(40 \mathrm{mg}, 0.026 \mathrm{mmol})$ was heated to reflux for $2 \mathrm{~h}$, after which time the solution was allowed to cool, and the solvent was removed under reduced pressure. The residue was separated by TLC on silica gel, furnishing three bands using cyclohexane $/ \mathrm{CH}_{2} \mathrm{Cl}_{2}(7: 3, \mathrm{v} / \mathrm{v})$ as the mobile phase. The first band afforded $\mathrm{Ru}_{2}(\mathrm{CO})_{6}(\mu-$ $\left.\mathrm{GePh}_{2}\right)\left(\mu\right.$-dppm) (3) (8 mg, 31\%), and the second band gave $\mathrm{Ru}_{3}(\mathrm{CO})_{6}\left(\mathrm{GePh}_{3}\right)(\mu-\mathrm{OH})(\mu-$ dppm) $(\mu-\mathrm{H})_{2}(6)(5 \mathrm{mg}, 16 \%)$ as yellow crystals after recrystallization from hexane/ $\mathrm{CH}_{2} \mathrm{Cl}_{2}$ at $25{ }^{\circ} \mathrm{C}$. The contents of the third band were too small for complete characterization. Analytical and spectroscopic data for 6: Anal. Calcd for $\mathrm{C}_{50} \mathrm{H}_{40} \mathrm{GeO}_{8} \mathrm{P}_{2} \mathrm{Ru}_{3}$ : C, 49.76; $\mathrm{H}$ 3.34. Found: $\mathrm{C}$ 50.17; H 3.39\%. IR ( $\left.v \mathrm{CO}, \mathrm{CH}_{2} \mathrm{Cl}_{2}\right): 2059 \mathrm{vs}, 2022 \mathrm{~m}, 2005 \mathrm{vs}, 1983 \mathrm{sh}, 1952 \mathrm{~m} \mathrm{~cm}^{-1} .{ }^{1} \mathrm{H} \mathrm{NMR}$ $\left(\mathrm{CDCl}_{3}\right): \delta 7.7(\mathrm{~m}, 5 \mathrm{H}), 7.75(\mathrm{~m}, 3 \mathrm{H}), 7.45(\mathrm{~m}, 15 \mathrm{H}), 7.21(\mathrm{~m}, 3 \mathrm{H}), 7.19(\mathrm{~m}, 3 \mathrm{H}), 6.45(\mathrm{~m}$, 6H), 4.50 (m, 1H), 3.50 (m, 6H), 0.27 (d, J 4.2 Hz, 1H), -12.3 (d, J 17.2 Hz, 1H), -11.8 (d, J $7.6 \mathrm{~Hz}, 1 \mathrm{H}) .{ }^{31} \mathrm{P}\left\{{ }^{1} \mathrm{H}\right\} \mathrm{NMR}\left(\mathrm{CDCl}_{3}\right): \delta 29.1(\mathrm{~d}, \mathrm{~J} 67.0 \mathrm{~Hz}, 1 \mathrm{P}), 34.0(\mathrm{~d}, \mathrm{~J} 67.0 \mathrm{~Hz}, 1 \mathrm{P})$.

\subsection{Thermolysis of 2 in the presence of $\mathrm{H}_{2} \mathrm{O}$}

One drop of water was added to a THF solution of $2(10 \mathrm{mg}, 0.007 \mathrm{mmol})$ and the resulting mixture was heated to reflux for $2 \mathrm{~h}$. The solvent was removed under vacuum and the residue chromatographed by TLC on silica gel. Elution with cyclohexane/ $\mathrm{CH}_{2} \mathrm{Cl}_{2}(7: 3$, $\mathrm{v} / \mathrm{v})$ developed one major and two very minor bands. The major band corresponded to $\mathrm{Ru}_{3}(\mathrm{CO})_{6}(\mu-\mathrm{OH})(\mu-\mathrm{dppm})(\mu-\mathrm{H})_{2}(\mathbf{6})(2 \mathrm{mg}, 25 \%)$, while the contents of the two other trace bands were too small for characterization.

\section{7. $X$-ray structure determination}

Single crystals of $\mathbf{1}, \mathbf{3}$, and $\mathbf{6}$ suitable for X-ray diffraction analyses were grown by slow diffusion of hexane into a dichloromethane solution containing each product at $4{ }^{\circ} \mathrm{C}$. 
Suitable single crystals of $\mathbf{1}, \mathbf{3}$, and $\mathbf{6}$ were mounted on an AgilentSuperNova dual diffractometer (Agilent Technologies Inc., Santa Clara, CA) using a Nylon Loop and the diffraction data were collected at $150(1) \mathrm{K}$ using Mo-K $\alpha$ radiation $(\lambda=0.71073)$. Unit cell determination, data reduction, and absorption corrections were carried out using CrysAlisPro [36]. The structures were solved with the ShelXS [37] structure solution program by direct methods and refined by full matrixleast-squareson $F^{2}$ using SHELX 2013 [38] within the OLEX2 [39] graphical user interface. Non-hydrogen atoms were refined anisotropically, and hydrogen atoms were included in the refinement using a riding model (except for the hydrides in $\mathbf{1}$ and $\mathbf{6}$ which here located in the electron density difference map of each cluster). The asymmetric unit of $\mathbf{3}$ contains a disordered dichloromethane in two sites and disordered water molecules in two sites. The hydrogen atoms of these molecules were not included in the refinement.

\subsection{Computational Methodology}

The DFT calculations were carried out with the Gaussian 09 package of programs [40] using the B3LYP hybrid functional. This functional is comprised of Becke's threeparameter hybrid exchange functional (B3) [41] and the correlation functional of Lee, Yang, and Parr (LYP) [42]. The ruthenium and germanium atoms were described with the StuttgartDresden effective core potential and SDD basis set, [43] and the 6-31G(d') basis set [44] was employed for all remaining atoms.

All reported geometries were fully optimized, and the analytical Hessian was evaluated at each stationary point to determine whether the geometry was an energy minimum (no negative eigenvalues) or a transition structure (one negative eigenvalue). Unscaled vibrational frequencies were used to make zero-point and thermal corrections to the electronic energies, and the resulting free energies are reported in $\mathrm{kcal} / \mathrm{mol}$ relative to the specified standard. Intrinsic reaction coordinate (IRC) calculations were performed on all transition-state structures in order to establish the reactant and product species associated with each transition-state structure. The geometry-optimized structures have been drawn with the JIMP2 molecular visualization and manipulation program [45].

\section{Acknowledgments}


This research has been sponsored by the Ministry of Science and Technology, Government of the People's Republic of Bangladesh. Part of this work was carried out by S. E. K. at the University of Göttingen. S. E. K. gratefully acknowledges the von Humboldt Foundation for a Fellowship to spend time at the University of Göttingen. M. G. R. thanks the Robert A. Welch Foundation (grant B-1093) for financial support and acknowledges computational resources through UNT's High-Performance Computing Services and CASCaM. We also thank Prof. Michael B. Hall (TAMU) for providing us a copy of his JIMP2 program.

\section{Supplementary data}

CCDC 1511057, CCDC 1511058, and CCDC 1511059 contain supplementary crystallographic data for $\mathbf{1}, \mathbf{3}$, and $\mathbf{6}$, respectively. These data may be obtained free of charge from The Cambridge Crystallographic Data Center via www.ccdc.cam.ac.uk/data request/cif, while the atomic coordinates of all optimized structures are available from MGR upon request.

\section{References}

[1] (a) N. Macleod, J.R. Fryer, D. Stirling, G. Webb, Catal. Today 46 (1998) 37;

(b) G. Lafaye, C. Micheaud-Especel, C. Montassier, P. Marecot, Appl. Catal. A: Gen. 230 (2002) 19;

(c) G. Lafaye, C. Micheaud-Especel, C. Montassier, P. Marecot, Appl. Catal. A: Gen. 257 (2004) 107;

(d) T. Ekou, A. Vicente, G. Lafaye, C. Especel, P. Marecot, Appl. Catal. A: Gen. 314 (2006) 73.

[2] (a) R. Burch, J. Catal. 71 (1981) 348;

(b) R. Burch, L.C. Garla, J. Catal. 71 (1981) 360;

(c) T. Fujikawa, F.H. Ribeiro, G. A. Somorjai, J. Catal. 178 (1998) 58;

(d) Y.-K. Park, F.H. Ribeiro, G.A. Somorjai, J. Catal. 178 (1998) 66;

(e) R.D. Cortright, J.A. Dumesic, J. Catal. 148 (1997) 771;

(f) F.M. Dautzenberg, J.N. Helle, P. Biolen, W.M.H. Sachtler, J. Catal. 63 (1980) 119 ; 
(g) J.W. Shabaker, D.A. Simonetti, R.D. Cortright, J.A. Dumesic, J. Catal. 231 (2005) 67;

(h) R. Srinivasan, B.H. Davis, Platinum Met. Rev. 36 (1992) 151;

(i) F. Epron, C. Carnevillier, P. Marecot, Appl. Catal. 295 (2005) 157.

[3] (a) G.W. Huber, J.W. Shabaker, J.A. Dumesic, Science 300 (2003) 2075;

(b) M. Guidotti, V. Dal Aanto, A. Gallo, E. Gianotti, G. Peli, R. Psaro,

L. Sordelli, Catal. Lett. 112 (2006) 89;

(c) R.D. Cortright, J.M. Hill, J.A. Dumesic, Catal. Today 55 (2000) 213;

(d) B.F.G. Johnson, S.A. Raynor, D.B. Brown, D.S. Shephard, T. Mashmeyer, J.M.

Thomas, S. Hermans, R. Raja, G. Sankar, J. Mol. Catal. A: Chem. 182-183

(2002) 89;

(e) S. Hermans, B.F.G. Johnson, J. Chem. Soc., Chem. Commun. (2000) 1955;

(f) R.D. Adams, D.A. Blom, B. Captain, R. Raja, J.M. Thomas, E. Trufan, Langmuir 24 (2008) 9223.

[4] (a) S. Hermans, R. Raja, J.M. Thomas, B.F.G. Johnson, G. Sankar, D. Gleeson, Angew. Chem., Int. Ed. 40 (2001) 1211;

(b) J.M. Thomas, B.F.G. Johnson, R. Raja, G. Sankar, P.A. Midgley, Acc. Chem. Res. 36 (2003) 20;

(c) R.D. Adams, E.M. Boswell, B. Captain, A.B. Hungria, P.A. Midgley, R. Raja, J.M. Thomas, Angew. Chem., Int. Ed. 46 (2007) 8182;

(d) P. Braunstein, J. Rosé, In Catalysis by Di- and Polynuclear Metal Cluster Complexes, R.D. Adams, F.A. Cotton, Eds., Wiley-VCH: New York, 1998, Chapter 13;

(e) P. Braunstein, J. Rosé, In Metal Clusters in Chemistry, P. Braunstein, L.A. Oro, P.R. Raithby, Eds., Wiley-VCH: Weinheim, Germany, 1999, Vol. 2, Chapter 2.2, pp 616-677.

[5] (a) S.E. Kabir, A.K. Raha, M.R. Hassan, B.K. Nicholson, E. Rosenberg, A. Sharmin, L. Salassa, Dalton Trans. (2008) 4212.

(b) S. Ghosh, R. Pervin, A.K. Raha, S.E. Kabir, B.K. Nicholson, Inorg. Chim. Acta 362 (2009) 4226.

(c) A.K. Raha, S. Ghosh, I. Hossain, S.E. Kabir, B.K. Nicholson, G. Hogarth, L. Salassa, J. Organomet. Chem. 696 (2011) 2153; 
(d) J.C. Sarker, K.M. Uddin, M.S. Rahman, S. Ghosh, T.A. Siddiquee, D.A.

Tocher, M.G. Richmond, G. Hogarth, S.E. Kabir, Inorg. Chim. Acta 409 (2014) 320.

(e) S.E. Kabir, G. Hogarth, Coord. Chem. Rev. 253 (2009) 1285.

[6] M.R. Hassan, G. Hogarth, G.M.G. Hossain, S.E. Kabir, A.K. Raha, M.S. Saha, D.A. Tocher, Organometallics 26 (2007) 6473.

[7] M.R. Haque, M.J. Hossain, A. Rahaman, S. Ghosh, S.E. Kabir, G. Hogarth, D.A. Tocher, J. Organomet. Chem. 812 (2016) 240.

[8] M.M.M. Khan, S. Ghosh, G. Hogarth, D.A. Tocher, M.G. Richmond, S.E. Kabir, H.W. Roesky, J. Organomet. Chem. (submitted).

[9] (a) S. Hermans, R. Raja, J.M. Thomas, B.F.G. Johnson, G. Sankar, D. Gleeson, Angew. Chem., Int. Ed. 40 (2001) 40, 1211;

(b) S. Hermans, B.F.G. Johnson, Chem. Commun. (2000) 1955;

(c) R. Raja, T. Khimyak, J.M. Thomas, S. Hermans, B.F.G. Johnson, Angew.Chem., Int. Ed. 40 (2001) 4638.

[10] A. Tijani, B. Coq, F. Figueras, Appl. Catal. 76 (1991) 255.

[11] M.C. Sanchez-Sierra, J. García-Ruiz, M.G. Proietti, J.J. Blasco, Mol. Catal., A, 108 (1996) 95.

[12] M. Baya, P. Crochet, A.M. Esteruelas, E. Onãte, Organometallics 20 (2001) 240.

[13] G.R. Clark, K.R. Flower, C.E.F. Rickard, W.R. Roper, D.M. Salter, L.J.Wright, J. Organomet. Chem. 462 (1993) 331.

[14] W.K. Leong, F.W.B. Einstein, R.K. Pomeroy, Organometallics 15 (2001) 1589.

[15] J. Howard, P. Woodward, J. Chem. Soc. (A), (1971) 3648.

[16] Y. Zhang, B. Wang, S. Xu, X. Zhou, Organometallics 20 (2001)3829.

[17] J.A. Cabeza, P. García-Alvarez, D. Polo, Inorg. Chem. 50 (2011) 6195.

[18] (a) J.A. Cabeza, P. Garcia-Alvarez, D. Polo, Inorg. Chem. 51 (2012) 2569-2576;

(b) J.A. Cabeza, P. Garcia-Alvarez, D. Polo, Dalton Trans. 42 (2013) 1329-1332;

(c) J.A. Cabeza, P. Garcia-Alvarez, E. Perez-Carreno, D. Polo, Chem. Eur. J. 20 (2014) 8654-8663;

(d) J.A. Cabeza, J.M. Fernandez-Colinas, P. Garcia-Alvarez, D. Polo, RSC Adv. 4 (2014) 31503-31506.

[19] (a) J.A. Cabeza, P. Garcia-Alvarez, E. Perez-Carreno, D. Polo, Inorg. Chem. 53 (2014) 8735-8741; 
(b) L. Alvarez-Rodriguez, J.A. Cabeza, P. Garcia-Alvarez, E. Perez-Carreno, D. Polo, Inorg. Chem. 54 (2015) 2983-2994;

(e) J.A. Cabeza, J.M. Fernandez-Colinas, P. Garcia-Alvarez, E. Perez-Carreno, D. Polo, Inorg. Chem. 54 (2015) 4850-4861;

(g) J.A. Cabeza, P. Garcia-Alvarez, R. Gobetto, L. Gonzalez-Alvarez, C. Nervi, E. Perez-Carreno, D. Polo, Organometallics 35 (2016) 1761-1770.

[20] L. Alvarez-Rodriguez, J.A. Cabeza, P. Garcia-Alvarez, D. Polo, Coord. Chem. Rev. 300 (2015) 1-28.

[21] (a) R.D. Adams, B. Captain, W. Fu, M.D. Smith, Inorg. Chem. 41 (2002) 2302;

(b) R.D. Adams, B. Captain, W. Fu, M.D. Smith, Inorg. Chem. 41 (2002) 5593;

(c) R.D. Adams, B. Captain, J.L. Smith, Jr, M.B. Hall, C.L. Beddie, C.E. Webster, Inorg. Chem. 43 (2004) 7576;

(d) R.D. Adams, B. Captain, L. Zhu, Organometallics 25 (2006) 2049;

(e) R.D. Adams, B. Captain, M.B. Hall, E. Trufan, X. Yang, J. Am. Chem. Soc. 129 (2007) 12328;

(f) R.D. Adams, E. Trufan, Organometallics 27 (2008) 4108;

(g) R.D. Adams, B. Captain, L. Zhu, Organometallics 25 (2006) 4183;

(h) R.D. Adams, B. Captain, E. Trufan, J. Organomet. Chem. 693 (2008) 3593;

(i) J.D. Cotton, S.A.R. Knox, F.G.A. Stone, J. Chem. Soc., Chem. Commun. (1967) 965.

[22] (a) R.D. Adams, B. Captain, L. Zhu, Inorg. Chem. 44 (2005) 6623;

(b) R.D. Adams, E.M. Boswell, B. Captain, M.A. Patel, Inorg. Chem. 46 (2007) 533;

(c) R.D. Adams, B. Captain, E. Trufan, J. Clust. Sci. 18 (2007) 642;

(d) R.D. Adams, M. Chen, E. Trufan, J. Organomet. Chem. 696 (2011) 2894;

(e) R.D. Adams, Y. Kan, Q. Zhang, Organometallics 31 (2012) 8639;

(f) R.D. Adams, Y. Kan, V. Rassolov, Q. Zhang, J. Organomet. Chem. 730 (2013) 20 ;

(g) S.A.R. Knox, F.G.A. Stone, J. Chem. Soc. (A) (1971) 2874.

[23] (a) J.A. Cabeza, I. del Rio, J.M. Fernandez-Colinas, M.G. Sanchez-Vega, Organometallics 28 (2009) 1243-1247;

(b) C. Bois, J.A. Cabeza, R.J. Franco, V. Riera, E. Saborit, J. Organomet. Chem. 564 (1998) 201-207;

(c) J.A. Cabeza, I. del Rio, V. Riera, Inorg. Chim. Acta 268 (1998) 131-133; 
(d) J.A. Cabeza, R.J. Franco, V. Riera, S. Garcia-Granda, J.F. Van der Maelen, Organometallics 14 (1995) 3342-3348.

[24] (a) J.A. Cabeza, R.J. Franco, V. Riera, Inorg. Chem. 33 (1994) 5952-5954;

(b) J.A. Cabeza, R.J. Franco, A. Llamazares, V. Riera, C. Bois, Y. Jeannin, Inorg. Chem. 32 (1993) 4640-4642;

(c) J.A. Cabeza, S. Garcia-Granda, A. Llamazares, V. Riera, J.F. Van der Maelen, Organometallics 12 (1993) 157-163;

(d) J.A. Cabeza, A. Llamazares, V. Riera, S. Triki, L. Ouahab, Organometallics 11 (1992) 3334-3339.

[25] J.A.K Howard, P. Woodward, P. J. Chem. Soc., Dalton Trans. (1978) 412.

[26] M.J. Hossain, S. Rajbangshi, M.M.M. Khan, S. Ghosh, G. Hogarth, E. Rosenberg, K.I. Hardcastle, M.G. Richmond, S.E. Kabir,J. Organomet. Chem. 767 (2014) 185.

[27] M.M.M. Khan, S. Ghosh, G. Hogarth, D.A. Tocher, M.G. Richmond, H.W. Roesky, S.E. Kabir, J. Organomet. Chem. 840 (2017) 47.

[28] A.J. Deeming, M.M. Hassan, S.E. Kabir, E. Nordlander, D.A. Tocher, J. Chem. Soc., Dalton Trans. (2004) 3709.

[29] (a) S.-H. Huang, J.M. Keith, M.B. Hall, M.G. Richmond, Organometallics 29 (2010) 4041 ;

(b) X. Zhang, S. Kandala, L. Yang, W.H. Watson, X. Wang, D.A. Hrovat, W.T. Borden, M.G. Richmond, Organometallics 30 (2011) 1253;

(c) M.K. Hossain, S. Rajbangshi, A. Rahaman, M.A.H. Chowdhury, T.A. Siddiquee, S. Ghosh, M.G. Richmond, E. Nordlander, G. Hogarth, S.E. Kabir, J. Organomet. Chem. 760 (2014) 231.

[30] (a) L.R. Nevinger, J.B. Keister, Organometallics 9 (1990) 2312;

(b) M. Day, D. Espitia, K.I. Hardcastle, S.E. Shariff, E. Rosenberg, R. Gobetto, L. Milone, D. Osella, Organometallics 10 (1991) 3550;

(c) E. Rosenberg, R. Kumar, J. Clust. Sci. 25 (2014) 239.

[31] N. Lugan, J.-J. Bonnet, J.A. Ibers, J. Am. Chem. Soc. 107 (1985) 4484.

[32] H. Hashimoto, Y. Hayashi, I. Aratani, C. Kabuto, M. Kira, Organometallics 21 (2002) 1534.

[33] A.J. Deeming, D.M. Speel, M. Stchedroff, Organometallics 16 (1997) 6004.

[34] N. Begum, U.K. Das, M. Hassan, G. Hogarth, S.E. Kabir, E. Nordlander, M. A. Rahman, D.A. Tocher, Organometallics 26 (2007) 6462.

[35] M.I. Bruce, B.K. Nicholson, M.L. Williams, Inorg. Synth. 26 (1990) 265. 
[36] CrysAlisPro; Oxford Diffraction: Yarnton, England, 2015.

[37] O.V. Dolomanov, L.J. Bourhis, R.J. Gildea, J.A.K. Howard, H. Puschmann, J. Appl. Crystallogr. 42 (2009) 339.

[38] G.M. Sheldrick, Acta Crystallogr., Sect. A: Found. Crystallogr. 64 (2008) 112.

[39] O.V. Dolomanov, L.J. Bourhis, R.J. Gildea, J.aK. Howard, H. Puschmann, J. Appl. Crystallogr. 42 (2009) 339.

[40] M.J. Frisch, G.W. Trucks, H.B. Schlegel, G.E. Scuseria, M.A. Robb, J.R. Cheeseman, G. Scalmani, V. Barone, B. Mennucci, G.A. Petersson, H. Nakatsuji, M. Caricato, X. Li, H. P. Hratchian, A.F. Izmaylov, J. Bloino, G. Zheng, J.L. Sonnenberg, M. Hada, M. Ehara, K. Toyota, R. Fukuda, J. Hasegawa, M. Ishida, T. Nakajima, Y.Honda, O. Kitao, H. Nakai, T. Vreven, J.A. Montgomery, Jr., J.E. Peralta, F. Ogliaro, M. Bearpark, J.J. Heyd, E. Brothers, K.N. Kudin, V.N. Staroverov, R. Kobayashi, J. Normand, K. Raghavachari, A. Rendell, J.C. Burant, S.S. Iyengar, J. Tomasi, M. Cossi, N. Rega, J.M. Millam, M. Klene, J.E. Knox, J.B. Cross, V. Bakken, C. Adamo, J. Jaramillo, R. Gomperts, R.E. Stratmann, O. Yazyev, A.J. Austin, R. Cammi, C. Pomelli, J.W. Ochterski, R.L. Martin, K. Morokuma, V.G. Zakrzewski, G.A. Voth, P. Salvador, J.J. Dannenberg, S. Dapprich, A.D. Daniels, O. Farkas, J.B. Foresman, J.V. Ortiz, J. Cioslowski, D.J. Fox, Gaussian 09, Revision A.02, Gaussian, Inc., Wallingford CT, 2009.

[41] A.D. Becke, J. Chem. Phys. 98 (1993) 5648.

[42] C. Lee, W. Yang, R.G. Parr, Phys. Rev. B 37 (1988), 785.

[43] (a) M. Dolg, U. Wedig, H. Stoll, H. Preuss, J. Chem. Phys. 86 (1987) 866;

(b) S.P. Walch, C.W. Bauschlicher, J. Chem. Phys. 78 (1983)4597.

[44] (a) G.A. Petersson, A. Bennett, T.G. Tensfeldt, M.A. Al-Laham, W.A. Shirley, J. Mantzaris, J. Chem. Phys. 89 (1988)2193;

(b) G.A. Petersson, M.A. Al-Laham, J. Chem. Phys. 94 (1991)6081.

[45] (a) JIMP2, version 0.091, a free program for the visualization and manipulation of molecules: M.B. Hall, R.F. Fenske, Inorg. Chem. 11 (1972) 768;

(b) J. Manson, C.E. Webster, M.B. Hall, Texas A\&M University, College Station, TX, 2006: http://www.chem.tamu.edu/jimp2/index.html. 
Table 1. Crystallographic and structure refinement data for 1, 3, and $\mathbf{6}$

\begin{tabular}{|c|c|c|c|}
\hline Compound & 1 & 3 & 6 \\
\hline Empirical formula & $\mathrm{C}_{52} \mathrm{H}_{38} \mathrm{GeO}_{9} \mathrm{P}_{2} \mathrm{Ru}_{3}$ & $\mathrm{C}_{44.5} \mathrm{H}_{32} \mathrm{Cl}_{4.5} \mathrm{GeO}_{7} \mathrm{P}_{2} \mathrm{Ru}_{2}$ & $\mathrm{C}_{50} \mathrm{H}_{40} \mathrm{GeO}_{8} \mathrm{P}_{2} \mathrm{Ru}_{3}$ \\
\hline Formula weight & 1244.56 & 1174.89 & 1206.56 \\
\hline Temperature (K) & $151(1)$ & $150(1)$ & $150.0(1)$ \\
\hline Wavelength ( $\mathrm{A})$ & 0.71073 & 1.54184 & 0.71073 \\
\hline Crystal system & Monoclinic & Monoclinic & Monoclinic \\
\hline Space group & $P 2_{1} / c$ & $C 2 / c$ & $P 2{ }_{1} / c$ \\
\hline Unit cell dimensions & & & \\
\hline$a(\AA)$ & $19.3490(4)$ & $36.9809(3)$ & $11.19783(18)$ \\
\hline$b(\AA)$ & $10.26517(18)$ & $12.09412(11)$ & $14.7835(2)$ \\
\hline$c(\AA)$ & $25.0369(5)$ & 21.9992(2) & $29.2473(4)$ \\
\hline$\alpha\left(^{\circ}\right)$ & 90 & 90 & 90 \\
\hline$\beta\left(^{\circ}\right)$ & $102.3642(18)$ & 97.9923(9) & $99.5847(15)$ \\
\hline$\gamma\left({ }^{\circ}\right)$ & 90 & 90 & 90 \\
\hline Volume $\left(\AA^{3}\right)$ & $4857.50(16)$ & $9743.57(16)$ & $4774.10(12)$ \\
\hline $\mathrm{Z}$ & 4 & 8 & 4 \\
\hline Density (calculated) $\left(\mathrm{g} / \mathrm{cm}^{3}\right)$ & 1.702 & 1.602 & 1.679 \\
\hline Absorption coefficient $\left(\mathrm{mm}^{-1}\right)$ & 1.650 & 8.964 & 1.674 \\
\hline$F(000)$ & 2464.0 & 4652.0 & 2392.0 \\
\hline Crystal size $\left(\mathrm{mm}^{3}\right)$ & $0.29 \times 0.20 \times 0.12$ & $0.30 \times 0.04 \times 0.03$ & $0.28 \times 0.12 \times 0.04$ \\
\hline $2 \theta$ range for data collection $\left({ }^{\circ}\right)$ & 5.834 to 58.776 & 8.116 to 148.278 & 5.828 to 56.006 \\
\hline Index ranges & $-26 \leq h \geq 25$ & $-45 \leq h \geq 45$ & $-14 \leq h \geq 14$ \\
\hline & $-13 \leq k \geq 14$ & $-14 \leq k \geq 15$ & $-19 \leq k \geq 18$ \\
\hline & $-34 \leq l \geq 34$ & $-27 \leq l \geq 24$ & $-37 \leq l \geq 37$ \\
\hline Reflections collected & 67613 & 78139 & 55306 \\
\hline Independent reflections & $9518\left[R_{\mathrm{int}}=0.0441\right]$ & $9784\left[R_{\mathrm{int}}=0.0639\right]$ & $9360\left[R_{\mathrm{int}}=0.0255\right]$ \\
\hline Data/restraints/parameters & $9518 / 0 / 608$ & $9784 / 0 / 535$ & $9360 / 0 / 589$ \\
\hline Goodness-of-fit on $F^{2}$ & 1.069 & 1.030 & 1.061 \\
\hline Final $R$ indices $[I>2 \sigma(I)]$ & $\begin{array}{l}R_{1}=0.0242 \\
w R_{2}=0.0542\end{array}$ & $\begin{array}{l}R_{1}=0.0690 \\
w R_{2}=0.1853\end{array}$ & $\begin{array}{l}R_{1}=0.0253 \\
w R_{2}=0.0606\end{array}$ \\
\hline$R$ indices (all data) & $\begin{array}{l}R_{1}=0.0283 \\
w R_{2}=0.0568\end{array}$ & $\begin{array}{l}R_{1}=0.0763 \\
w R_{2}=0.1941\end{array}$ & $\begin{array}{l}R_{1}=0.0291 \\
w R_{2}=0.0632\end{array}$ \\
\hline Largest diff. peak and hole $\left(e \AA^{-3}\right)$ & 1.10 and -0.62 & 2.57 and -2.39 & 0.69 and -0.62 \\
\hline
\end{tabular}




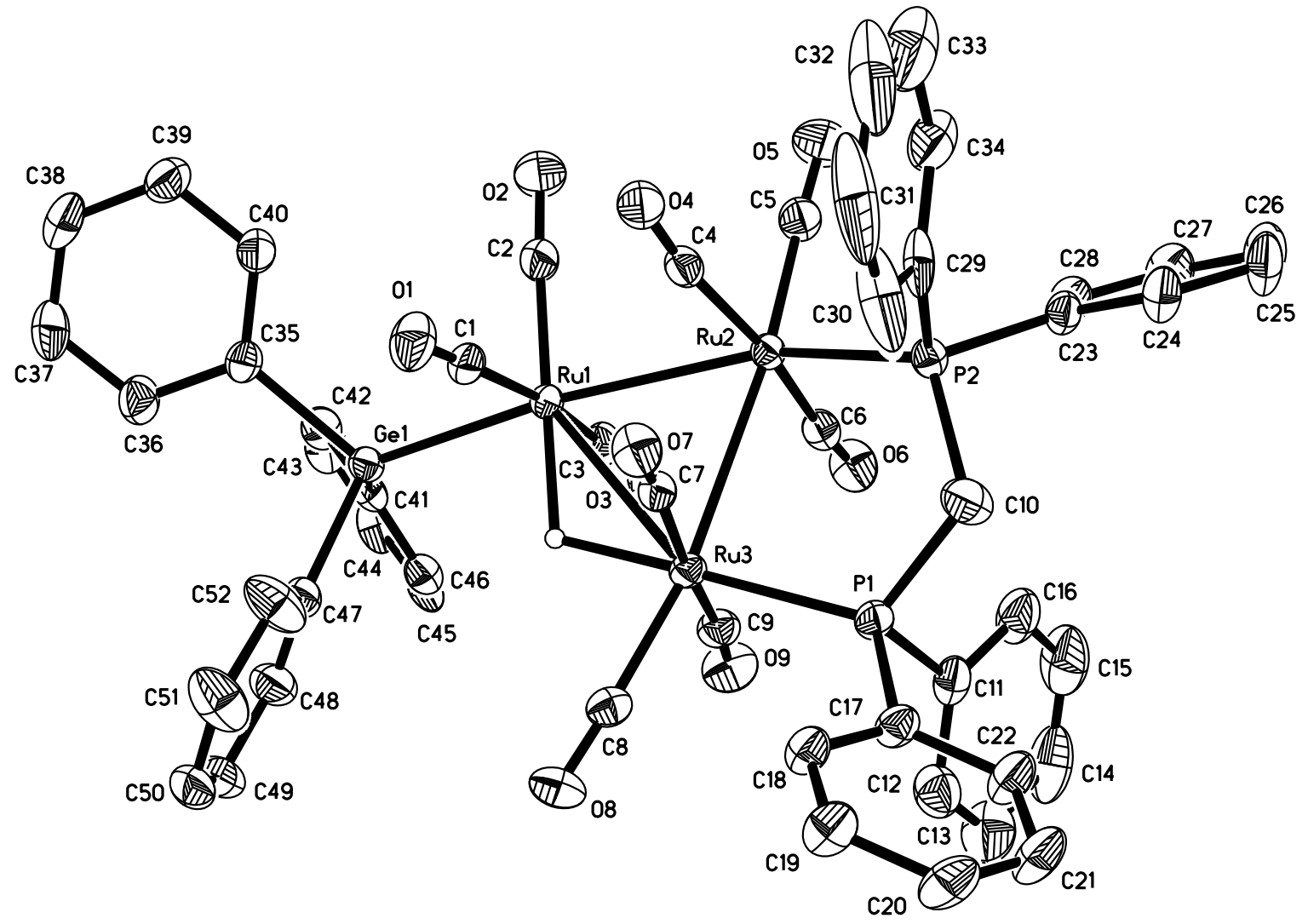

Fig. 1. ORTEP diagram of the molecular structure of $\mathrm{Ru}_{3}(\mathrm{CO})_{9}\left(\mathrm{GePh}_{3}\right)(\mu-\mathrm{dppm})(\mu-\mathrm{H})(\mathbf{1})$, showing $50 \%$ probability thermal ellipsoids. Hydrogen atoms omitted for clarity except for the bridging hydride associated with the $R u(1)-R u(3)$ vector. Selected bond lengths ( $\left({ }^{)}\right.$and angles $\left(^{\circ}\right): \operatorname{Ru}(1)-R u(2) 2.8441(3), R u(2)-R u(3)$ 2.8813(3), $\mathrm{Ru}(1)-\mathrm{Ru}(3)$ 3.0148(3), $\mathrm{Ru}(1)-\mathrm{Ge}(1)$ 2.5054(3), $\mathrm{Ru}(2)-\mathrm{P}(2)$ 2.3173(6), $\mathrm{Ru}(3)-\mathrm{P}(1)$ 2.3488(6), $\mathrm{Ru}(1)-\mathrm{Ru}(2)-\mathrm{Ru}(3)$ 63.544(7), $\mathrm{Ru}(1)-\mathrm{Ru}(3)-\mathrm{Ru}(2)$ 57.626(6), $\mathrm{Ru}(2)-\mathrm{Ru}(1)-\mathrm{Ru}(3)$ 58.830(6). 

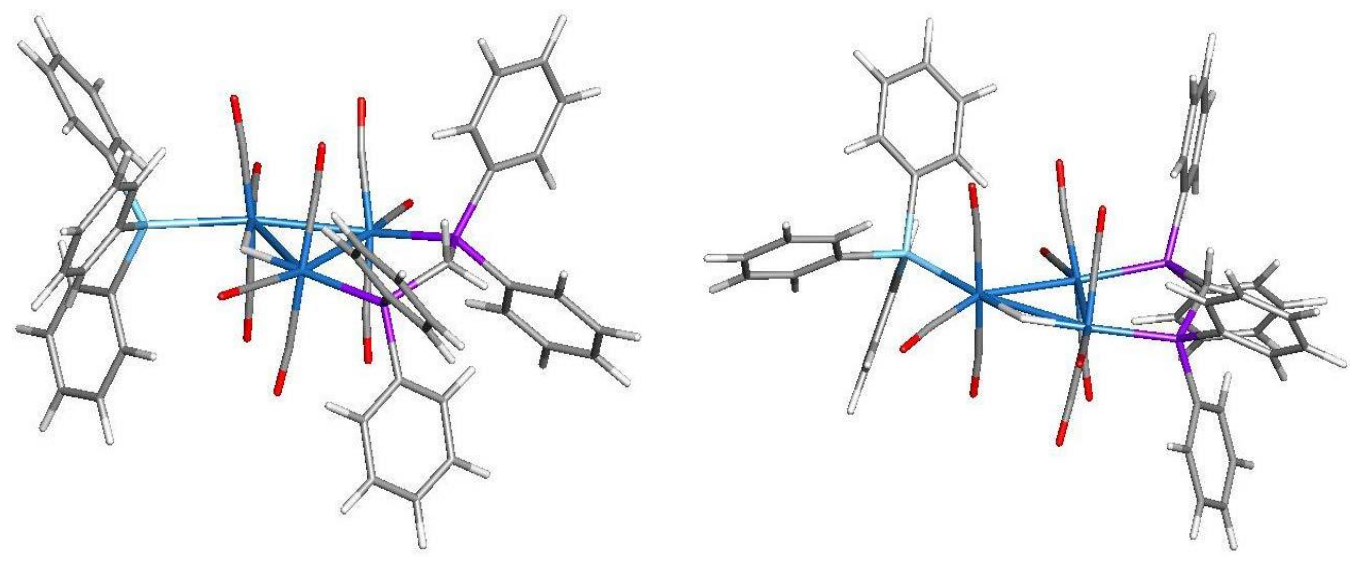

Fig. 2. DFT-optimized structures of the isomeric clusters $\mathbf{A 1}$ (left) and $\mathbf{A 2}$ (right) based on $\mathrm{Ru}_{3}(\mathrm{CO})_{9}\left(\mathrm{GePh}_{3}\right)(\mu-$ $\operatorname{dppm})(\mu-\mathrm{H})(\mathbf{1})$. 

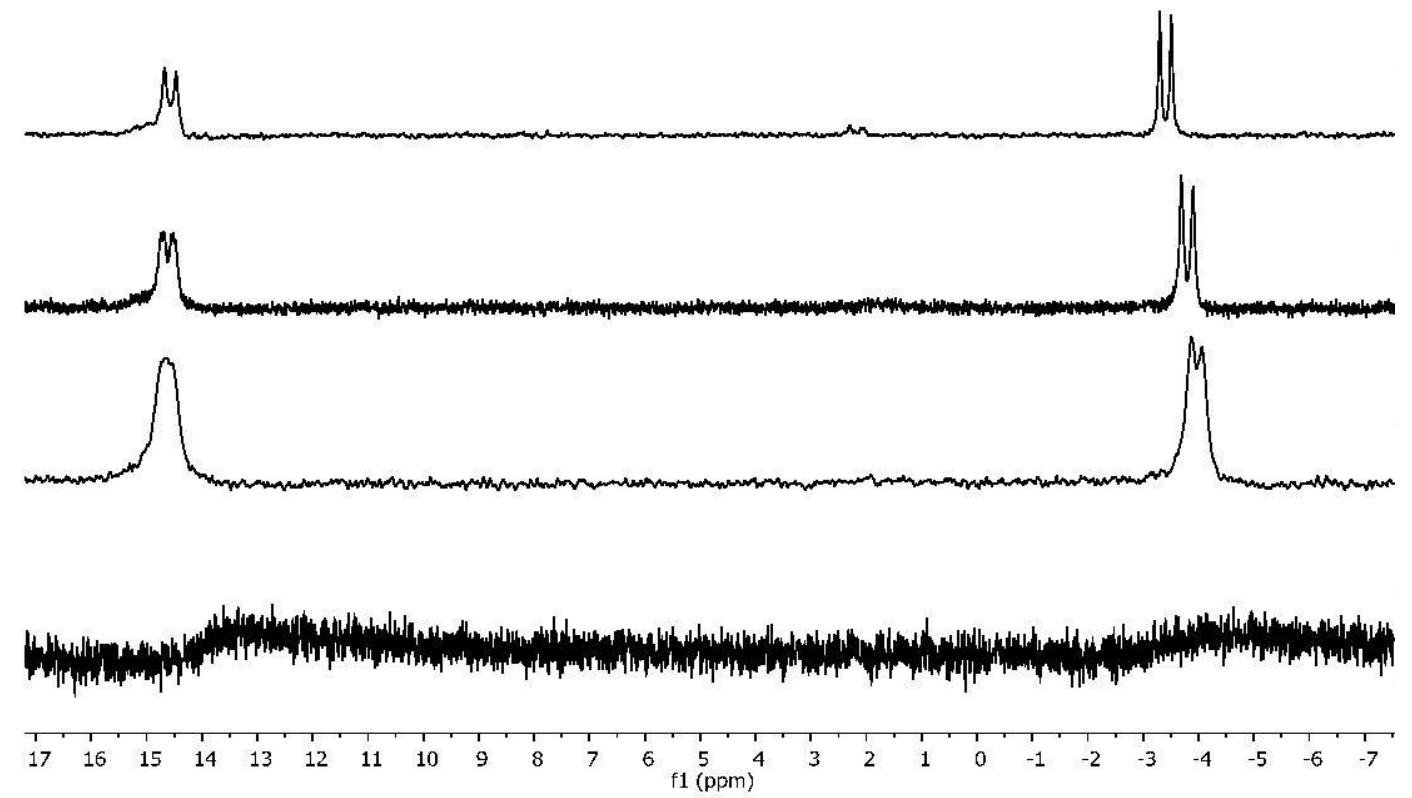

Fig. 3. Variable-temperature ${ }^{31} \mathrm{P}\left\{{ }^{1} \mathrm{H}\right\} \mathrm{NMR}$ spectra of $\mathrm{Ru}_{3}(\mathrm{CO})_{8}\left(\mathrm{GePh}_{3}\right)_{2}\left(\mu\right.$-dppm) $(\mu-\mathrm{H})_{2}(2)$ recorded (bottom to top) at $298 \mathrm{~K}, 263 \mathrm{~K}, 253 \mathrm{~K}$, and $233 \mathrm{~K}$.
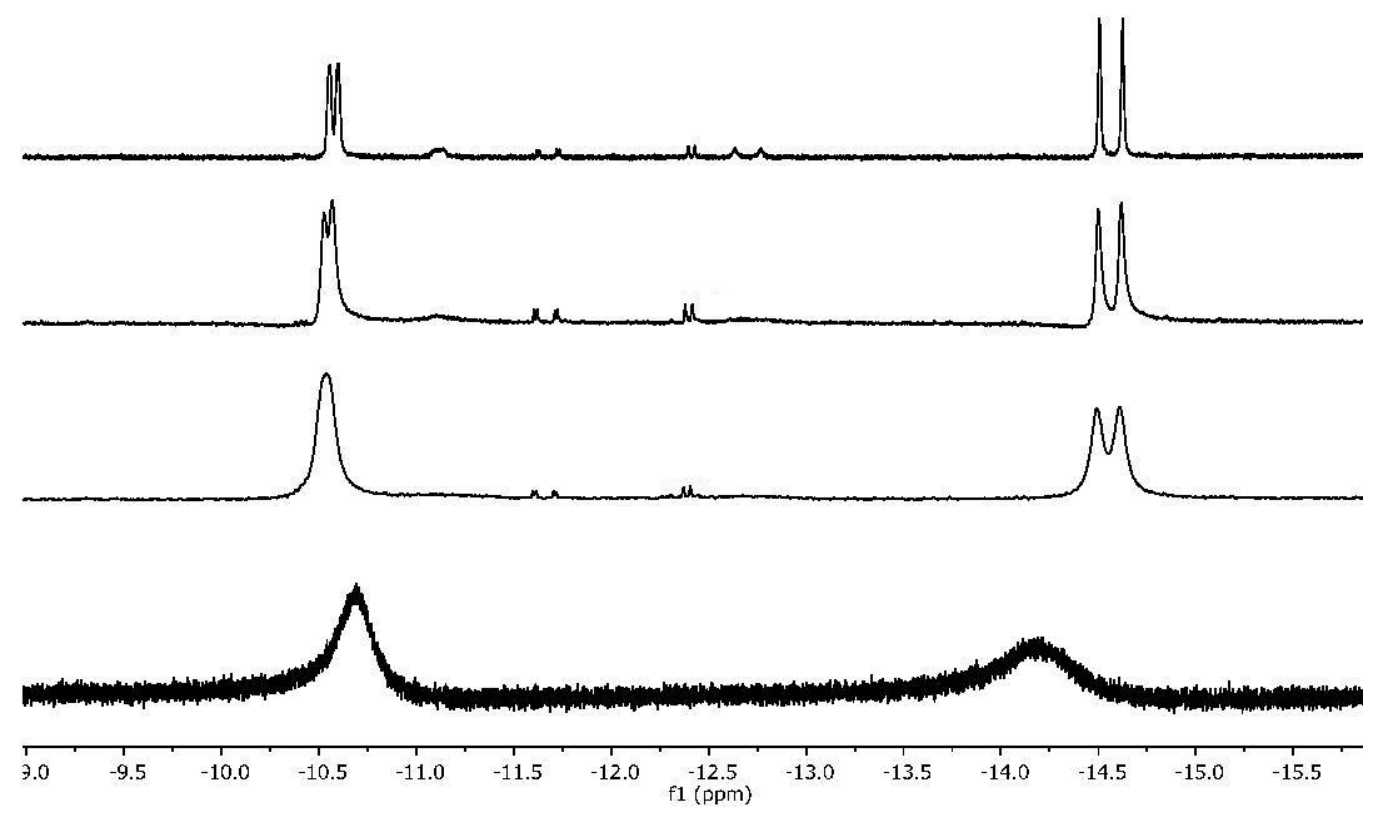

Fig. 4. Variable-temperature ${ }^{1} \mathrm{H}$ NMR spectra of the hydride region of $\left[\mathrm{Ru}_{3}(\mathrm{CO})_{8}\left(\mathrm{GePh}_{3}\right)_{2}(\mu\right.$-dppm $\left.)(\mu-\mathrm{H})_{2}\right](2)$ recorded (bottom to top) at $298 \mathrm{~K}, 263 \mathrm{~K}, 253 \mathrm{~K}$, and $233 \mathrm{~K}$. 


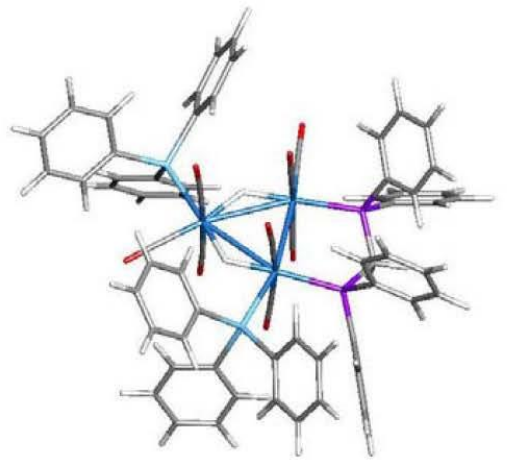

B1

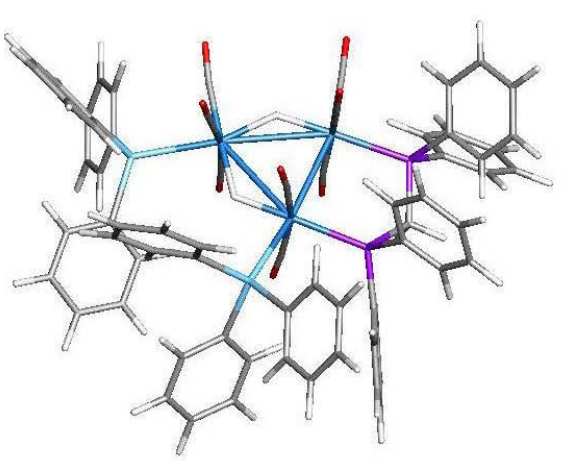

B4

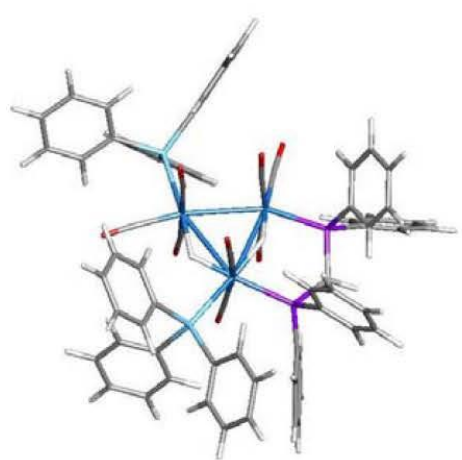

B2

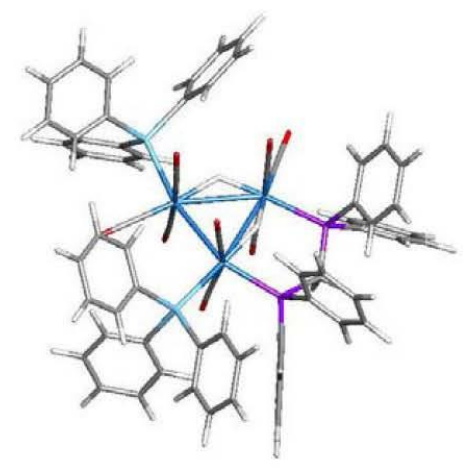

B5

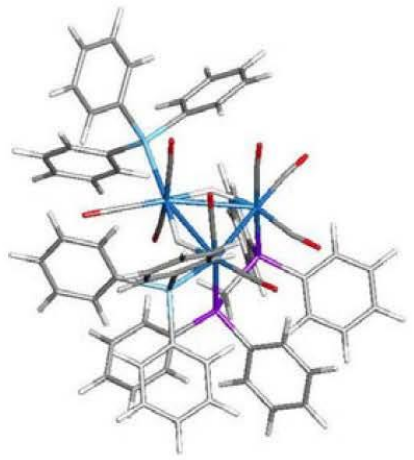

B3

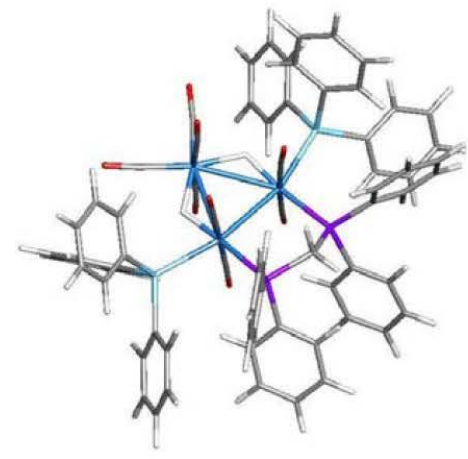

B6

Fig. 5. Optimized structures of the different isomers based on cluster 2 . 


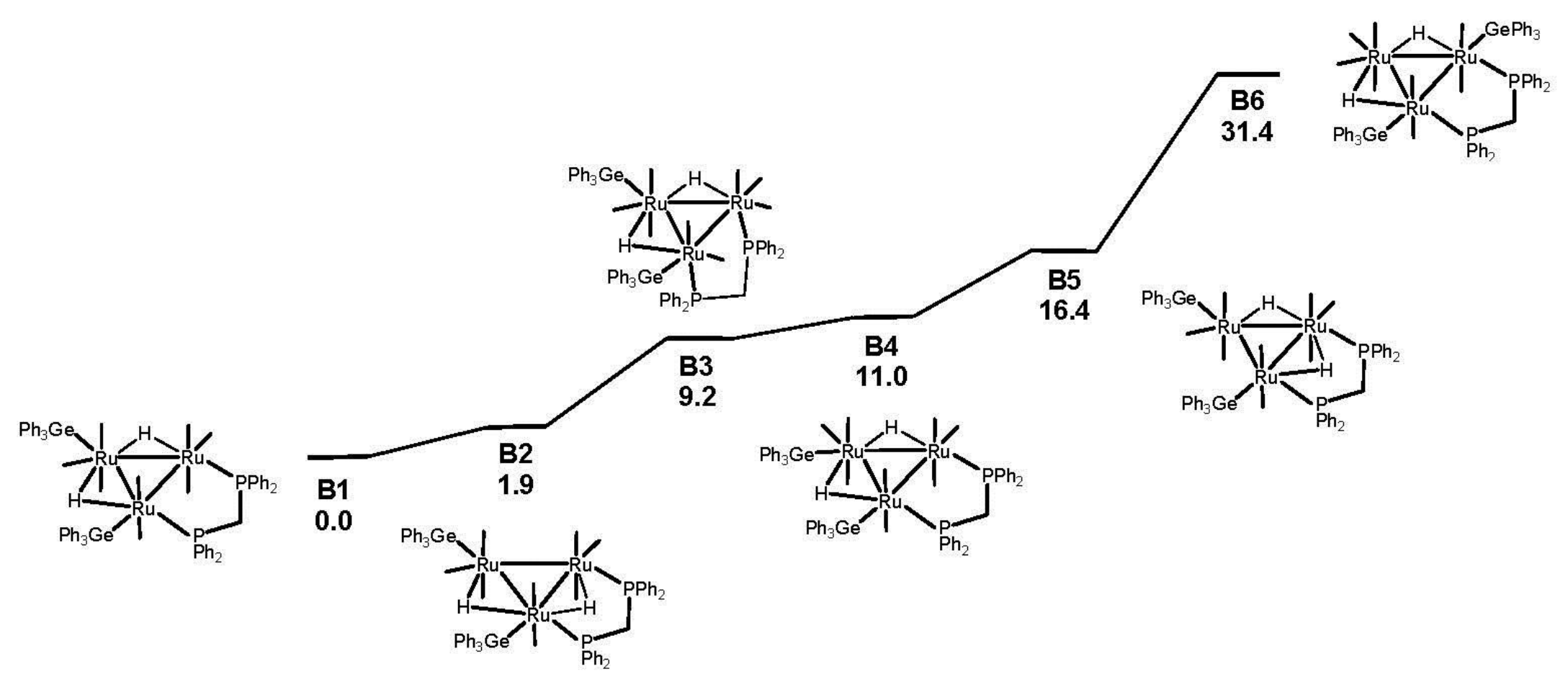

Fig. 6. Ground-state energy ordering for the optimized structures B1-B6. The quoted energies $(\Delta \mathrm{G})$ are in $\mathrm{kcal} / \mathrm{mol} \mathrm{relative}$ toB1. 


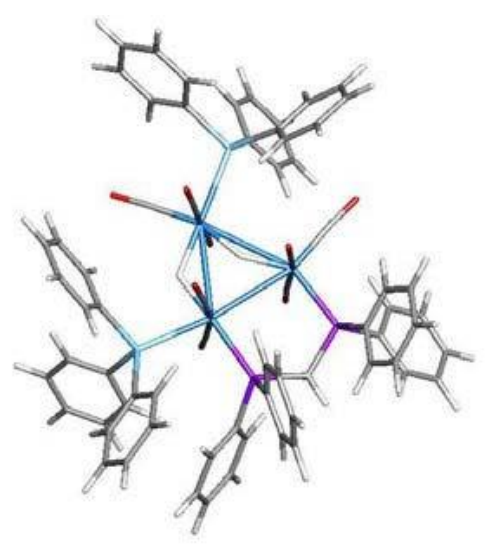

TSB1B2

10.8

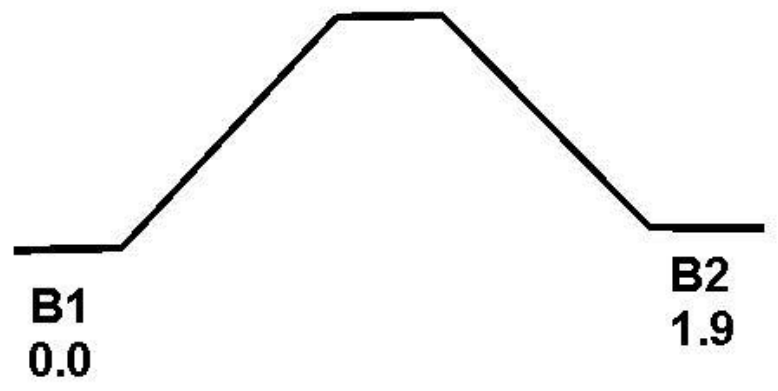

Fig. 7. Optimized B3LYP potential energy surface for the hydride exchange between the ground states B1 and B2 and TSB1B2. The quoted free energies $(\mathrm{kcal} / \mathrm{mol})$ are relative to species $\mathbf{B 1}$. 


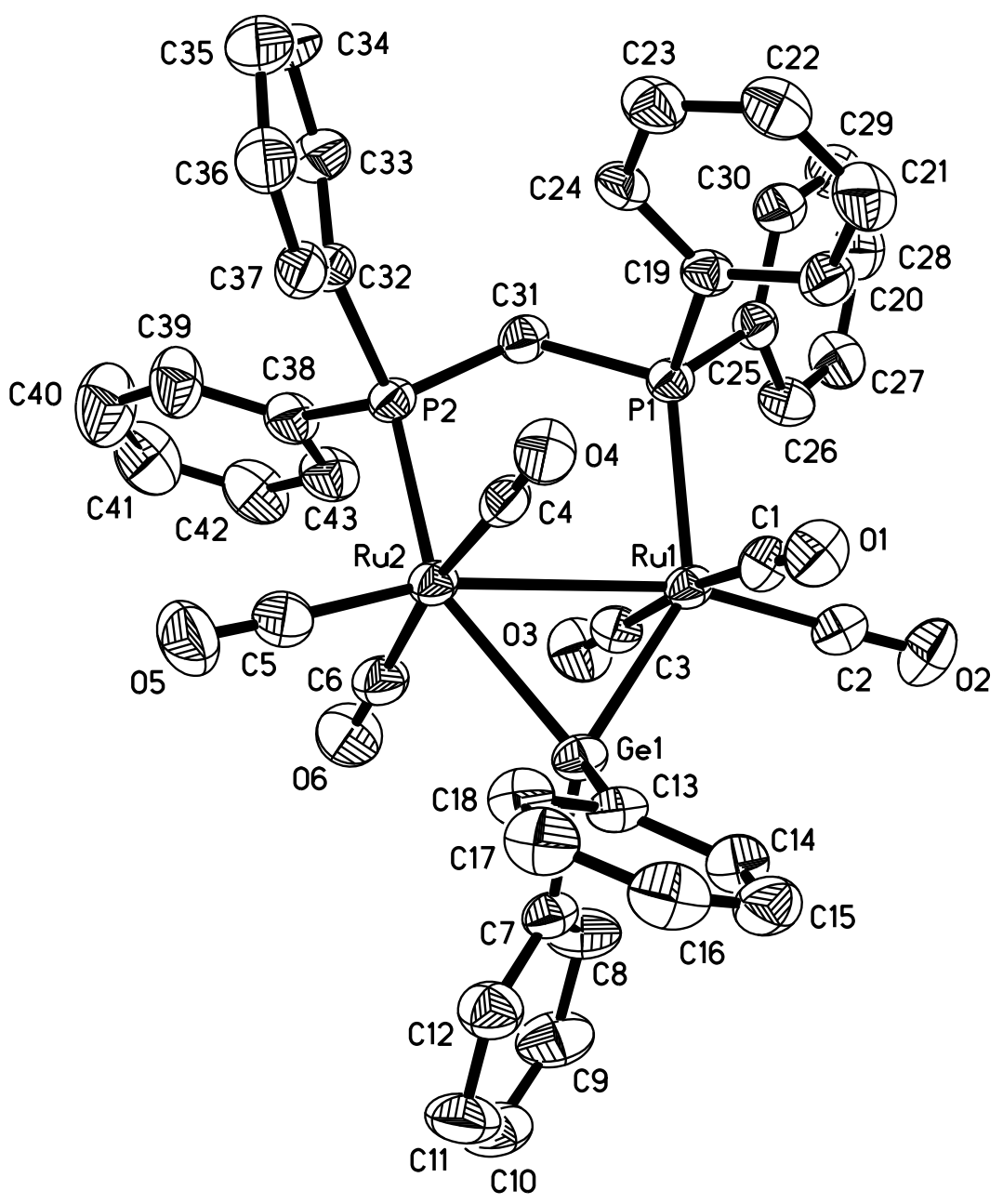

Fig. 8. ORTEP diagram of the molecular structure of $\mathrm{Ru}_{2}(\mathrm{CO})_{6}\left(\mu-\mathrm{GePh}_{2}\right)(\mu$-dppm) (3), showing $50 \%$ probability thermal ellipsoids. Hydrogen atoms are omitted for clarity. Selected bond lengths $(\AA)$ and angles $\left(^{\circ}\right)$ : $\mathrm{Ru}(1)-\mathrm{Ru}(2)$ 2.9293(6), Ru(1)-Ge(1) 2.5007(8), Ru(2)-Ge(1) 2.4881(8), Ru(1)-P(1) 2.3704(15), Ru(2)-P(2) 2.3712(15), Ge(1)-Ru(1)-Ru(2) 53.84(2), Ge(1)-Ru(2)-Ru(1) 54.24(2), Ge(1)-Ru(1)-P(1) 140.61(4), Ge(1)$\mathrm{Ru}(2)-\mathrm{P}(2) 148.20(5$. 


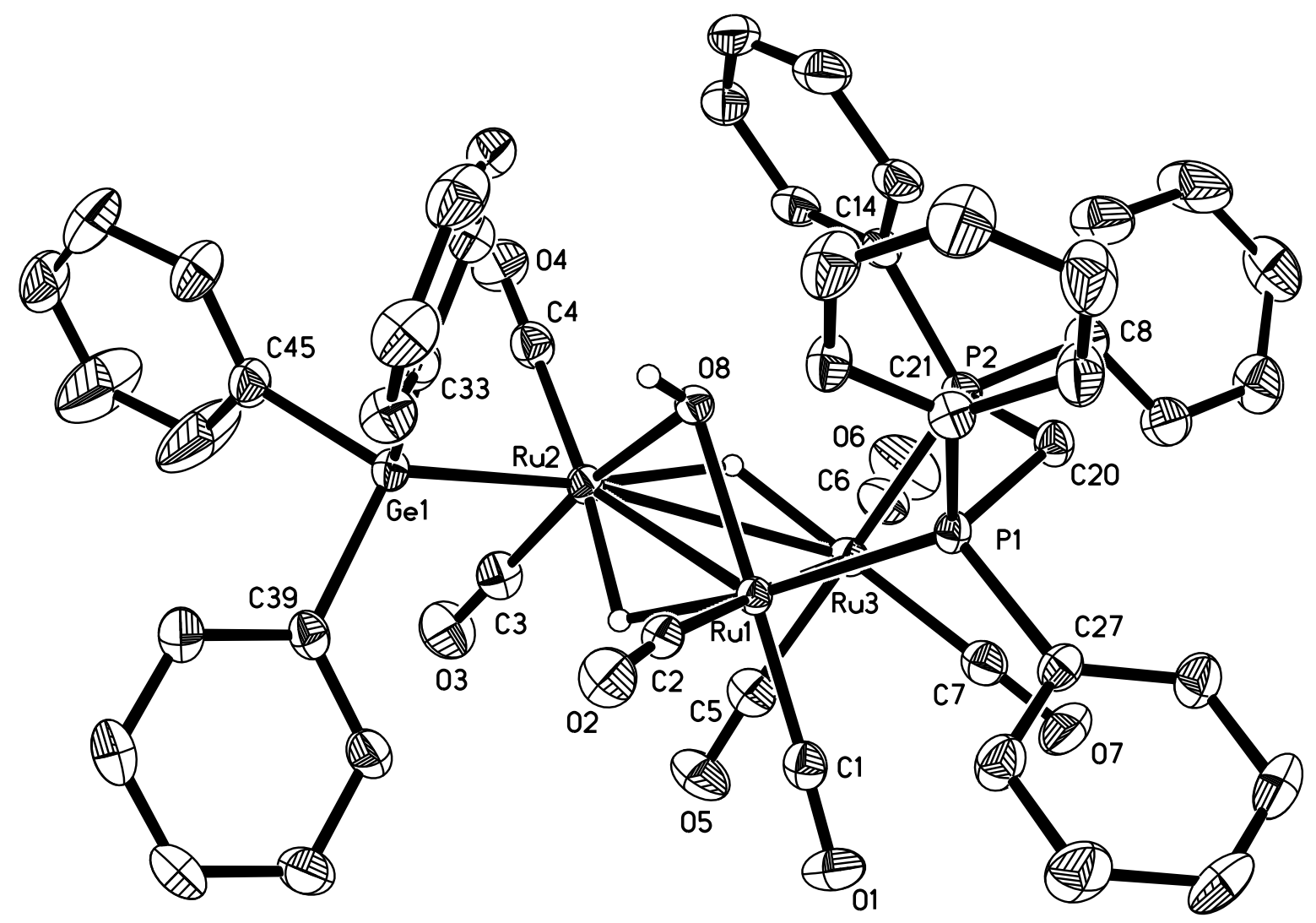

Fig. 9. ORTEP diagram of the molecular structure of $\mathrm{Ru}_{3}(\mathrm{CO})_{7}\left(\mathrm{GePh}_{3}\right)(\mu-\mathrm{OH})(\mu-\mathrm{dppm})(\mu-\mathrm{H})_{2}(6)$, showing $50 \%$ probability thermal ellipsoids. Hydrogen atoms are omitted for clarity except for the hydrides associated with the $\mathrm{Ru}(1)-\mathrm{Ru}(2)$ and $\mathrm{Ru}(2)-\mathrm{Ru}(3)$ vectors and the hydroxyl oxygen atom $\mathrm{O}(8)$. Selected bond lengths $(\AA)$ and angles $\left({ }^{\circ}\right): \operatorname{Ru}(1)-\operatorname{Ru}(2)$ 2.7775(3), Ru(1)-Ru(3) 2.8513(3), Ru(2)-Ru(3) 3.1051(3), Ru(2)-Ge(1) 2.4654(3), $\mathrm{Ru}(1)-\mathrm{P}(1)$ 2.3318(6), $\mathrm{Ru}(3)-\mathrm{P}(2)$ 2.3726(7), Ru(1)-O(8) 2.0985(17), Ru(2)-O(8) 2.0884(17), Ru(1)-Ru(2)$\mathrm{Ru}(3)$ 57.663(6), Ru(2)-Ru(1)-Ru(3) 66.945(7), Ru(1)-Ru(3)-Ru(2) 55.392(6). 

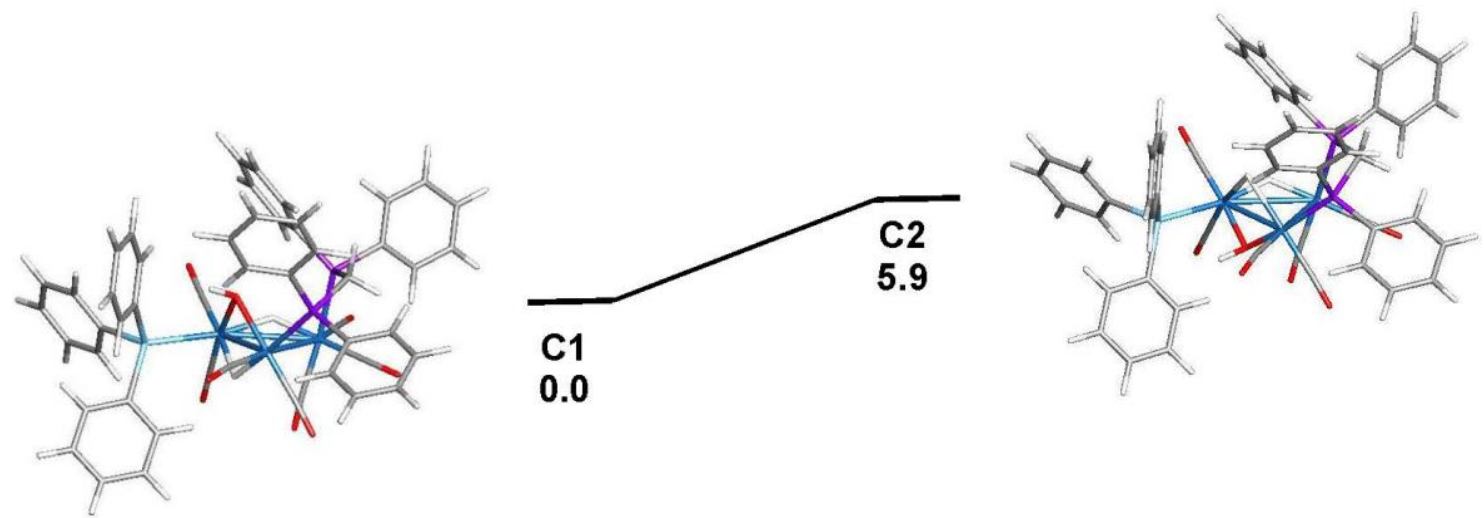

Fig. 10. Optimized B3LYP potential energy surface for the isomers based on species $\mathbf{C} \mathbf{1}$ and $\mathbf{C 2}$. The quoted free energies (kcal/mol) are relative to species $\mathbf{C 1}$. 


\section{Graphical Abstract}

Reactions of $\mathrm{Ru}_{3}(\mathrm{CO})_{10}(\mu-\mathrm{dppm})$ with $\mathrm{Ph}_{3} \mathrm{GeH}$ : $\mathrm{Ge}-\mathrm{H}$ and $\mathrm{Ge}-\mathrm{C}$ bond cleavage in $\mathrm{Ph}_{3} \mathrm{GeH}$ at triruthenium clusters

Md. Mehedi Mahabub Khan, Md. Mahbub Alam, Shishir Ghosh, Ahibur Rahaman, Derek A. Tocher, Michael G. Richmond, Shariff E. Kabir, Herbert W. Roesky

Structure and bonding of several dppm-ligated ruthenium-germanium complexes isolated from the reactions between $\mathrm{Ru}_{3}(\mathrm{CO})_{10}\left(\mu\right.$-dppm)and $\mathrm{Ph}_{3} \mathrm{GeH}$ have been investigated.

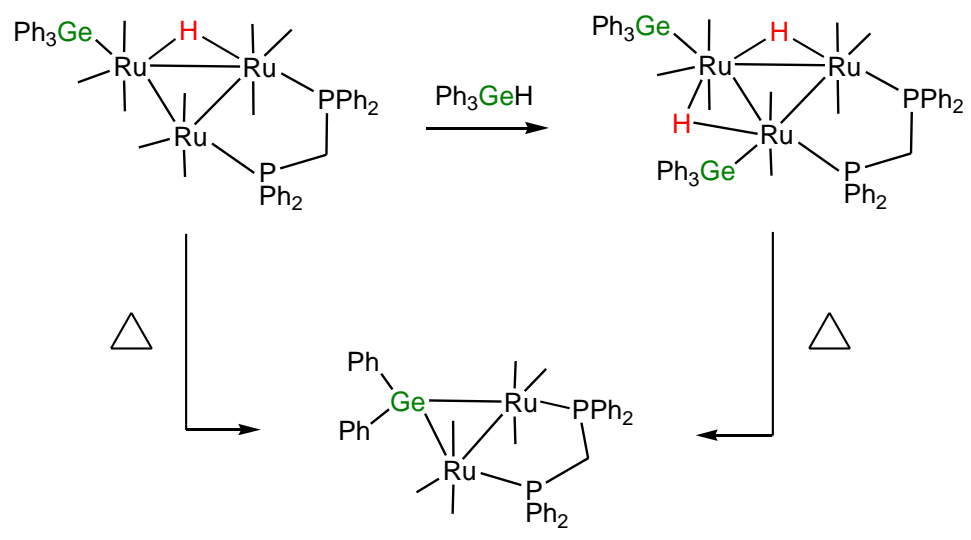

